\title{
路面補修前後の長期モニタリングから評価した 周期性路面の橋梁に及ぼす影響
}

\author{
深田 宰史 1 ・室井 智文 2 -樅山 好幸 3 ・梶川 康男 4 \\ 1正会員 金沢大学准教授 理工研究域環境デザイン学系（†920-1192 金沢市角間町） \\ E-mail: saiji@t.kanazawa-u.ac.jp \\ 2正会員 西日本高速道路エンジニアリング関西(株)（†567-0032 茨木市西駅前町5-26) \\ E-mail: t_muroi@w-e-kansai.co.jp \\ 3正会員＼cjkstart西日本高速道路エンジニアリング関西(株)（†567-0032 茨木市西駅前町5-26） \\ E-mail: momiyama@w-e-kansai.co.jp \\ 4正会員 金沢大学教授 理工研究域環境デザイン学系（†920-1192 金沢市角間町） \\ E-mail: kajikawa@t.kanazawa-u.ac.jp
}

\begin{abstract}
本研究で対象とした高速道路に架設されたPC桁橋は, 大型車両の走行に伴い, 車両と橋梁との連成振動 が生じ, 大きく振動していた. 本研究では, 試験車走行実験および路面計測により, その振動原因を路面 凹凸の周期性であると判断した。 そこで, 様々な走行速度, 重量およびばね特性を有した一般の大型車走 行によって生じた車両と橋梁との連成振動により，橋梁が受ける影響として，主桁の応力度がどの程度， 動的に増幅しているのか，2年間の長期モニタリングから明らかにした．さらに，その路面を補修したこ とにより, その忘力度がどの程度低減できたのか, 路面補修後の試験車走行実験と 1 年間の一般車走行を 対象としたモニタリングにより明らかにした。
\end{abstract}

Key Words : PC girder bridge, coupled vibration, road roughness, dynamic increment factor, monitoring

\section{1. まえがき}

高速道路をはじめとする道路ネットワークは, 高 度経済成長, 国民の生活水準やライフスタイルの向 上に貢献する重要な社会資本になっている. 近年, その社会資本の一役を構成する橋梁は, 大型車を含 めた交通量の増加，車両性能の向上に伴う高速化お よび多軸トレーラ車両などの車種の多様化など様々 な特性を有する走行荷重の影響を大きく受けている のが現状である.

そのような橋梁を取り巻く現状のもと, 本研究で 対象とした高速道路に架設されたPC桁橋は, 大型車 両の走行に伴い, 車両と橋梁の連成振動により, 大 きな振動を生じていた ${ }^{1)}$. 本研究では, その振動原 因を調べるためにまず試験車走行実験を行った。 そ の結果として, 対象橋梁のたわみ 1 次振動が $3 \mathrm{~Hz}$ 付近 に存在し, $3 \mathrm{~Hz}$ 付近に卓越振動数を有する車両の後 輪ばね上振動 ${ }^{2), 3)}$ と近接し, さらに, その連成振動 は, 試験車が第2走行車線を走行した場合のみ, 大
きな振動振幅を生じていた。

そこで，その要因を調べるために路面凹凸の調查 を行ったところ, 第2走行車線のみ伸縮継手付近の 路面凹凸が， $10 \mathrm{~m}$ 程度の周期性を有していた。この 周期性の路面凹凸の影響により，大型車両のばね上 振動が増幅され, その状態で橋梁に進入した大型車 両が橋梁との連成振動を励起させ, その結果, 橋梁 が大きく振動していたことを明らかにした.

本走行実験で得られた結果は, 走行速度, 重量, ばね特性が限られた試験車両によるものであり, 常 時の一般車走行による車両と橋梁との連成振動によ り，橋梁が受ける影響として，主桁の応力度がどの 程度, 動的に増幅しているのか不明であった。その ため，その路面凹凸を補修するまでの間，橋梁の振 動状況を監視する必要があると判断し，2年5ヶ月間 の振動モニタリングを行い，周期性路面を有する対 象橋梁の振動状況を明らかにした.

さらに，周期性を有した路面凹凸を補修し，路面 状況が改善されたことにより, 補修前の振動状況が 


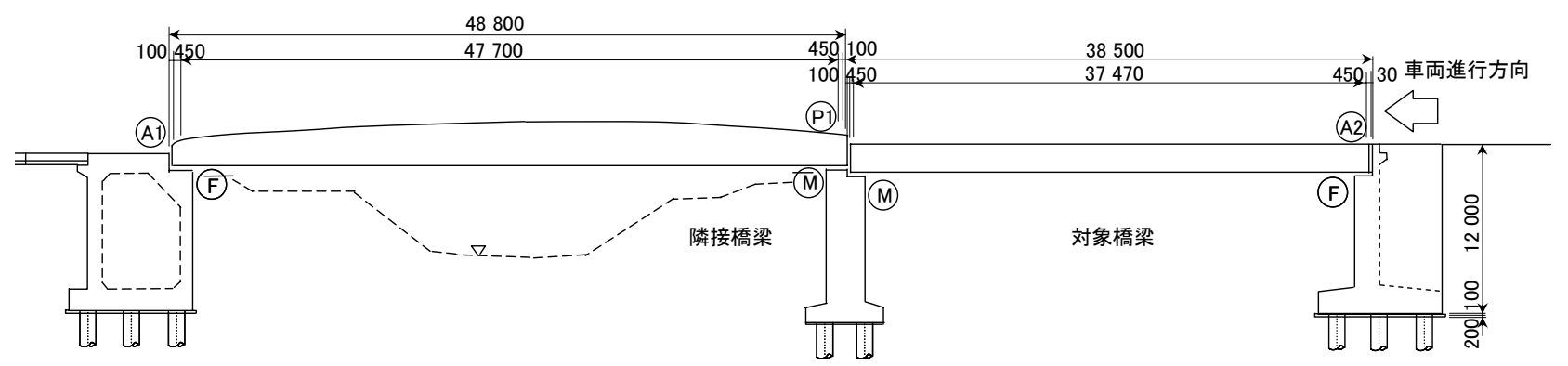

(a) 側面図
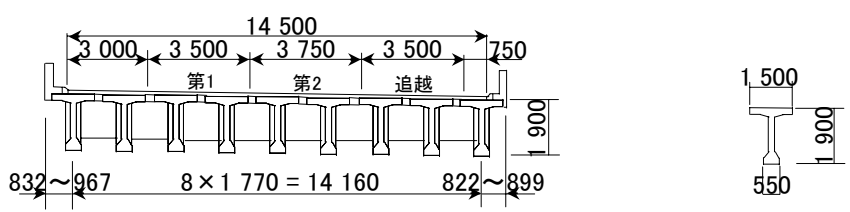

(b) 断面図

(c) PC ポストテンション $\mathrm{T}$ 桁

図-1 対象橋梁の一般図 (単位: $\mathrm{mm}$ )

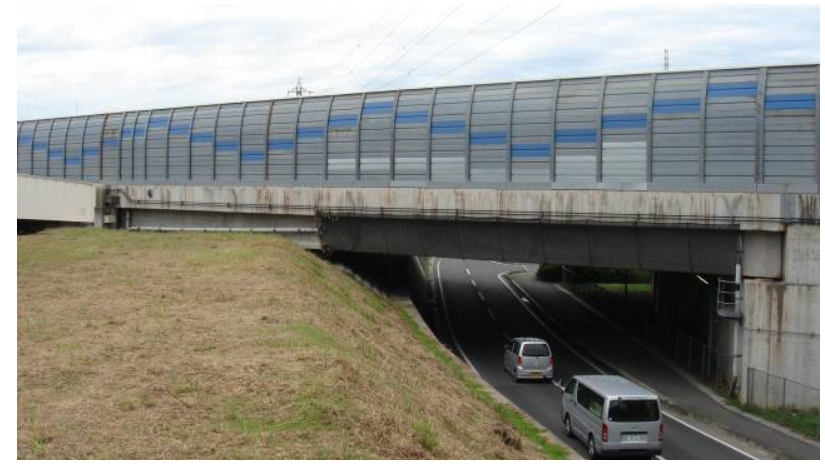

写真-1 対象橋梁（側面から）

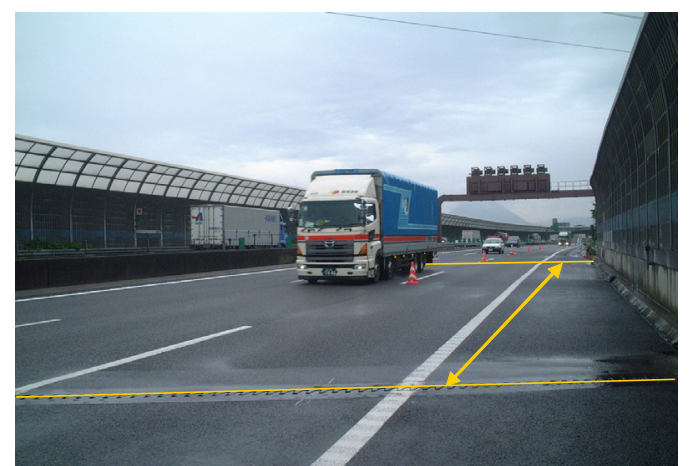

写真-2 対象橋梁（路面から）（矢印の区間）
どの程度改善されたのかを路面補修後の試験車走行 実験および1年間のモニタリングから明らかにした。

このような振動実験とモニタリング結果に対して, 解析からのアプローチとして，伸縮継手近傍に形成 された周期性を有した路面凹凸の波長と車両の走行 速度との関係から，橋梁の振動振幅がどの程度増幅 されるのか解明する必要があると考えた。

本研究では, 様々な波長の路面凹凸パターンを作 成して，車両走行シミュレーションを行うことによ り, 周期性路面による主枌振動の動的増幅率を求め, 周期性路面が橋梁に及ぼす影響について解析からも 明らかにした。

\section{2. 橋梁概要}

本研究において対象とした橋梁は, 日本初の高速 道路として開通した区間（栗東 IC から $2 \mathrm{~km}$ 付近） の下り線に位置する. 平成 9 年に完成した 6 車線化 改築事業の際に，交差する路下の県道の拡幅に伴い, カルバートボックスから橋梁構造（写真-1 参照） に改築された。桁高は, 通常よりも低く $1.9 \mathrm{~m}$ （ス
パン桁高比 1/19.7） となっている. 対象橋梁の側面 図を図-1 (a)に示す．対象橋梁は，支間長 $37.47 \mathrm{~m}$, 斜角 670 を有する PC ポストテンション単純 $\mathrm{T}$ 桁橋 である。また，断面は図-1 (b) に示すように有効幅 員 $14.5 \mathrm{~m}, 9$ 本の主桁から構成され，3 車線（写真2 参照）を有している. 図-1 (c) に 1 本の主桁（PC ポストテンション $\mathrm{T}$ 桁）断面を示す. また, 支承 は，ゴムパッド支承を用いている。

\section{3. モニタリングの動機}

定期点検により，ほぼ同支間を有する上り線の橋 梁に比べ，下り線の対象橋梁が異常に大きな振幅で 振動していることを発見した。対象橋梁ではたわみ 1 次振動 $(2.9 \sim 3.0 \mathrm{~Hz})$ と㸚じり 1 次振動（3.4〜 $3.6 \mathrm{~Hz}$ ）が主に卓越していた。特に，図-2 に示すよ うに $3 \mathrm{~Hz}$ 付近に後輪ばね上振動 ${ }^{2), 3)}$ を有するリーフ サスペンションの大型車両が第 2 走行車線を走行し た場合は，他の車線（第 1 走行車線，追越車線）を 走行した場合より，大きな振動をしていた。 


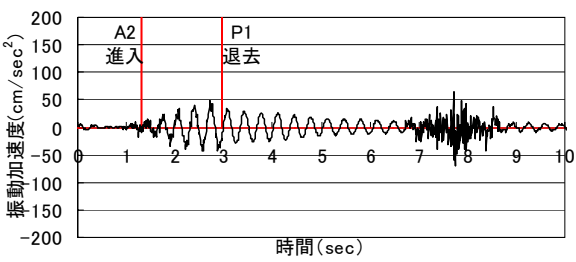

(a) 第 1 走行車線

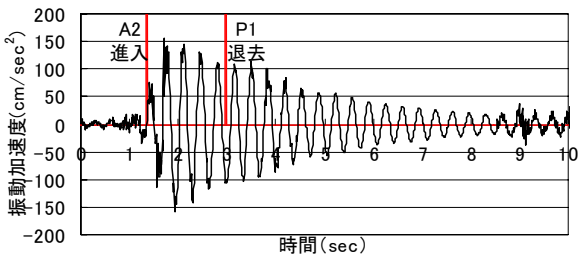

(b) 第 2 走行車線

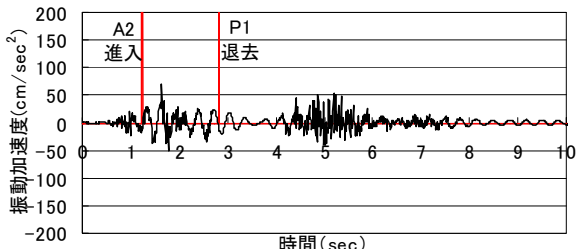

(c) 追越車線
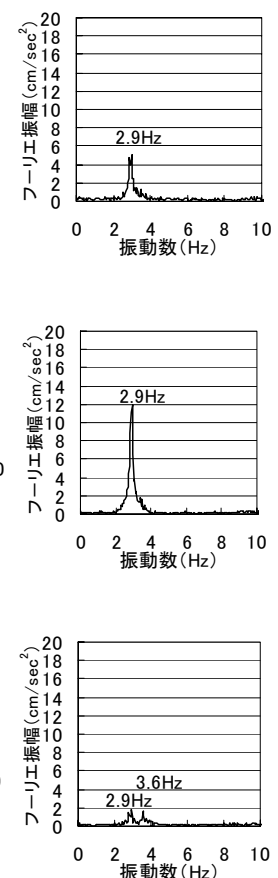

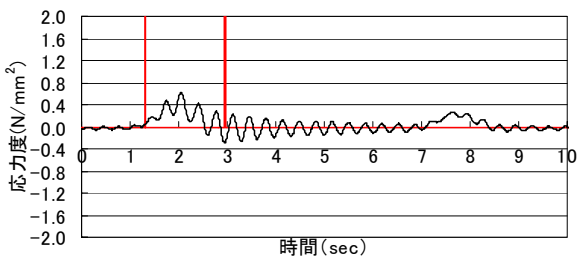

(a) 第 1 走行車線

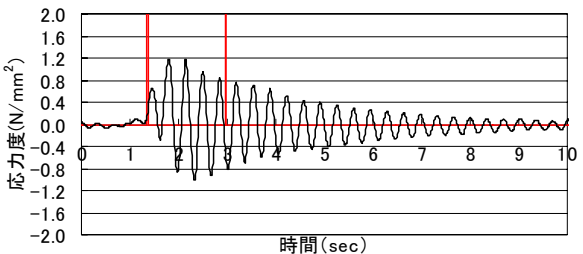

(b) 第 2 走行車線

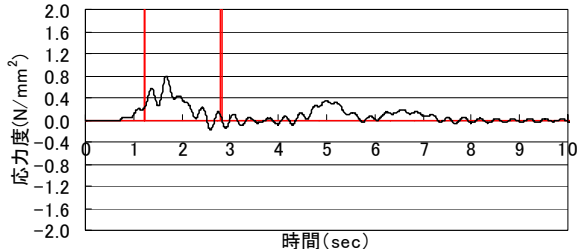

(c) 追越車線

図-2 3 軸トラック走行時の加速度 (支間中央追越側)

図-3 3 軸トラック走行時の応力度 (支間中央追越側)

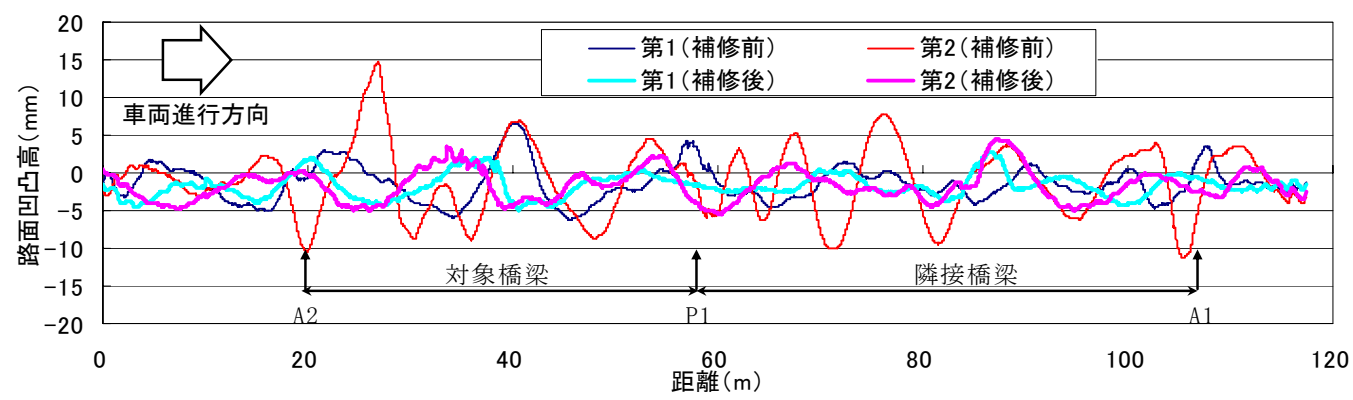

図-4 路面凹凸

また，主桁下面で計測したひずみから換算した応 力度は, 図-3 に示すように, 第 2 走行車線を走行 した場合は，他の車線を走行した場合より 2 倍程度 大きな応力度を示していた。

加振源となる大型車両と受振側となる橋梁のそれ ぞれの卓越振動数が近接していることから，車両と 橋梁の連成振動が生じていたことは明らかといえる が，第 2 走行車線を走行した場合のみ大きな振動を していたことから路面凹凸に原因があると判断した。

\section{4. 路面性状}

第 2 走行車線を走行した場合のみ大きな振動が生 じる要因を調べるために，路面凹凸の計測を行った。 図-4に 2009 年の路面補修前に路面計測車 ${ }^{4)}$ により 計測した路面凹凸波形を示す。その結果, 第 2 走行 車線のみ伸縮継手付近の路面凹凸が，10m 程度の
周期性を有し，大きな凹凸高となっていた.

この周期性を有した路面の影響により，大型車両 のばね上振動が増幅され，その状態で橋梁上を走行 するために車両と橋梁の連成振動が励起され, 対象 橋梁が大きく加振させられていたことが明らかにな った.

このような状況に対して，2009 年 5 月に路面補 修工事を行い，既設舗装（高機能舗装） $40 \mathrm{~mm}$ を切 削し，新設舗装（高機能舗装）を打ち直した。高さ 管理の方法は, 縦断方向 $5 \mathrm{~m}$ ごと水糸を横断方向に 張り, 周期性を有していない追越車線の路面高を基 準にして高さ調整を行った。補修工事は, 問題とな っている第 2 走行車線に加えて, 損傷状況を考慮し て第 1 走行車線に対しても行った. 図-4に路面補 修後の路面凹凸波形を示す.

この路面凹凸波形から, 補修前に比べて補修後で は，明らかに第 2 走行車線の周期性を有した路面性 状が改善されたことがわかる。また，対象橋梁区間 
表-1 IRI 評価（単位 $\mathrm{mm} / \mathrm{m}$ )

\begin{tabular}{|c|c|c|}
\hline 車線 & 補修前 & 補修後 \\
\hline 第1走行 & 1.50 & 0.97 \\
\hline 第2走行 & 3.53 & 1.33 \\
\hline 追越 & 1.13 & - \\
\hline
\end{tabular}
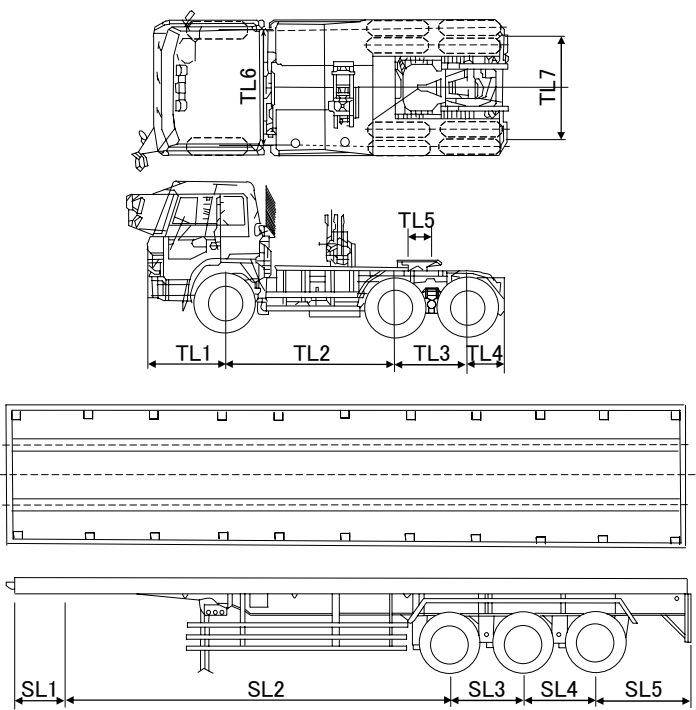

（a）試験車 $\mathrm{T} 1$ 〜 $\mathrm{T} 3 （$ トラクタ・セミトレーラ）

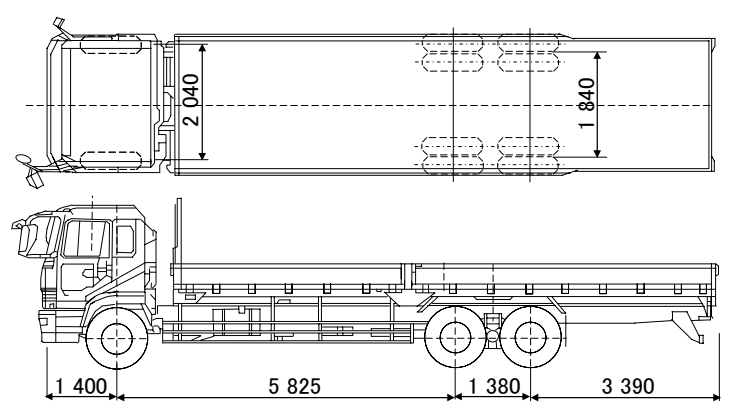

(b) 試験車 T4（3 軸トラック）

図-5 試験車両

表-2 車両諸元（トラクタ・セミトレーラ）（単位: $\mathrm{mm}$ )

\begin{tabular}{|c|c|c|c|c|}
\hline & \multicolumn{3}{|c|}{ トラクタ・セミトレーラ試験車 } \\
\hline & & $\overline{T 1}$ & $\mathrm{~T} 2$ & T3 \\
\hline \multirow{7}{*}{ タ } & $\overline{\text { TL1 }}$ & 1380 & 1380 & 1390 \\
\hline & $\overline{\text { TL2 }}$ & 3200 & 2955 & 3035 \\
\hline & TL3 & --- & 1300 & 1300 \\
\hline & $\overline{T \text { TL4 }}$ & 970 & 640 & 680 \\
\hline & TL5 & 640(車輪まで) & 90 & 200 \\
\hline & TL6 & 2055 & 2086 & 2040 \\
\hline & TL7 & 1840 & 1860 & 1840 \\
\hline \multirow{5}{*}{$\stackrel{\text { セ }}{ミ}$} & SL1 & 600 & 1100 & 800 \\
\hline & $\mathrm{SL2}$ & 6910 & 6500 & 6700 \\
\hline & SL3 & 1300 & 1300 & 1300 \\
\hline & $\overline{S L 4}$ & 1300 & 1300 & 1300 \\
\hline & SL5 & 1890 & 1650 & 1750 \\
\hline
\end{tabular}

で国際ラフネス指数 ${ }^{5), 6)}$ (以下，IRI）を計算したと ころ，表-1 に示すように，第 2 走行車線において は，補修前 $3.53 \mathrm{~mm} / \mathrm{m}$ となっており，明らかに他の 車線に比べて IRI が大きかった. これは, 縦断方向 の凹凸に対する補修目標值である IRI $3.5 \mathrm{~mm} / \mathrm{m}^{7)}$ に 達していたことになる. 補修後は $1.33 \mathrm{~mm} / \mathrm{m}$ に低減

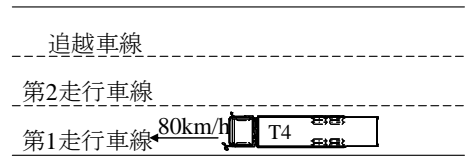

(a) ケース 1

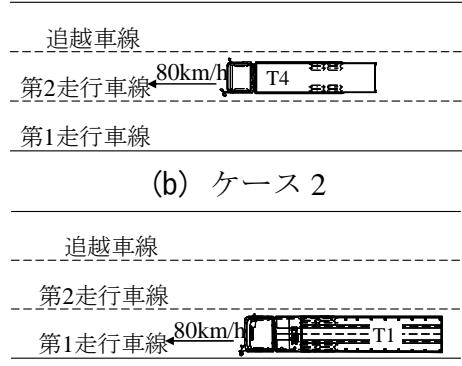

(c) ケース 3

追越車線
-第2走行車線 $80 \mathrm{~km} / \mathrm{C}$
第1走行車線

(d) ケース 4

追越車線 第2走行車線 $80 \mathrm{~km} / \mathrm{C}$ 第1走行車線 $80 \mathrm{~km} / \mathrm{T}$

(e) ケース 5

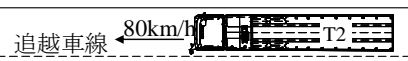

第2走行車線

第1走行車線 $80 \mathrm{~km} / \mathrm{T}$

(f) ケース 6

第2走行車線 $80 \mathrm{~km} / \mathrm{T} / \mathrm{T}$

(g) ケース 7

図-6 走行ケース

しており，IRI からも定量的に改善されたことがわ かる。

\section{5. 試験車走行実験}

\section{(1) 試験車両}

2009 年 5 月の路面補修工事に伴い, 本研究では, この補修工事前後において試験車走行実験を行い, 周期性を有した路面凹凸が橋梁上に存在する場合， 様々な車両走行パターンにより橋梁がどの程度振動 するのかを検討することにした。

試験車走行実験では，図-5 に示した 3 軸トラッ ク 1 台とトラクタ・セミトレーラ（以下，セミトレ ーラ） 3 台を用いた. トラクタ・セミトレーラにお ける車両諸元を表-2 に示す. 


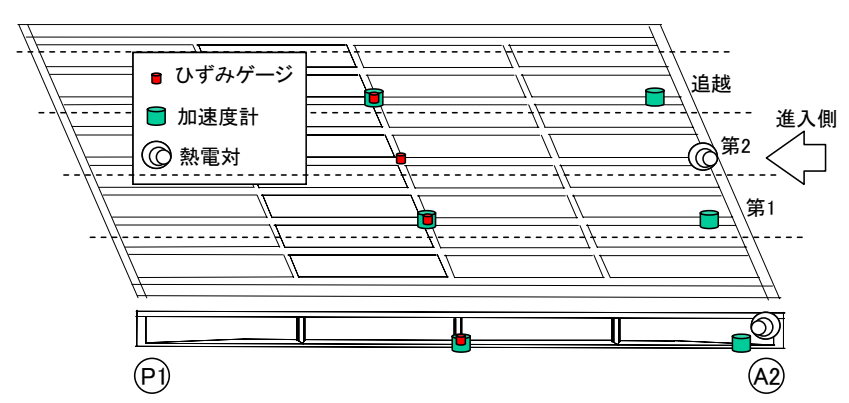

(a) 橋梁全体

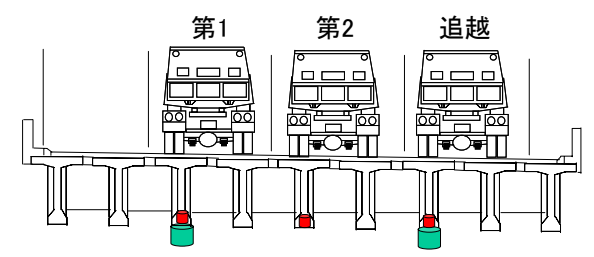

(b) 支間中央断面

図-7 橋梁の測点配置図

\section{（2）走行ケース}

実験では，3 軸トラックとセミトレーラの試験車 を組み合わせ，図-6 に示すような 7 つの走行ケー スで走行させた.

- 走行ケース 1 および走行ケース 2 は, 3 軸トラ ックが単独で第 1 走行車線および第 2 走行車線 を走行するケースである.

・ 走行ケース 3 および走行ケース 4 は, セミトレ ーラが単独で第 1 走行車線および第 2 走行車線 を走行するケースである. 3 軸トラックは, リ ーフサスペンションを有しているため, 後輪ば ね上の振動数が $3.0 \mathrm{~Hz}$ 付近にある. また, セミ トレーラの後輪 3 軸もリーフサスペンションで あり $3.4 \mathrm{~Hz}$ 付近に卓越振動があり, 若干 3 軸卜 ラックより高い振動数となっている. しかし, 3 軸トラックに比べてセミトレーラによる総重 量としての加振力は大きい.

- 走行ケース 5 および走行ケース 6 は, セミトレ 一ラが，第 1 走行車線と第 2 走行車線および第 1 走行車線と追越車線を並走するケースである. 重量が最も重い載荷ケースである。

・ 走行ケース 7 は, セミトレーラが第 1 走行車線, 3 軸トラックが第 2 走行車線を走行するケース である。

\section{（3）測点配置}

橋梁の測点配置図を図-7 に示寸. 支間中央断面 では，ひずみゲージを各車線下の主桁下フランジ下 面に設置し, 加速度計を第 1 走行車線と追越車線下 の主桁下フランジに設置した（図-7 (b) 参照）。ま た, A2 支点部から $3 \mathrm{~m}$ 離れた位置の第 1 走行車線

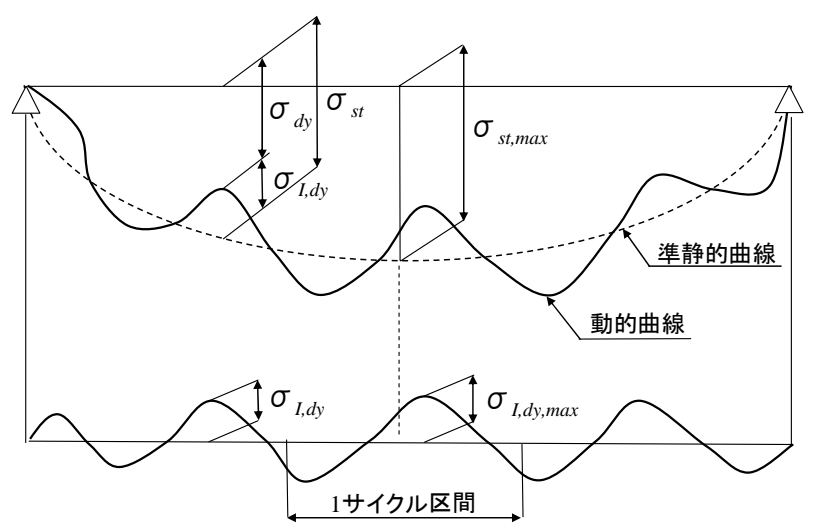

図-8 動的増幅率の概念

と追越車線下の主桁下フランジに加速度計を設置し た。ひずみゲージおよび加速度計の設置位置は, 車 線を走行する大型車両の左車輪位置になる.

\section{(4) 評価項目}

各走行ケースにおいて得られた応力度波形に対し て, ここでは動的増幅率 ${ }^{8)}$ を用いて路面補修前後に おける走行パターンの違いによる周期性路面が橋梁 に及ぼす動的な影響を評価することにした。

車両走行実験において得られる応力度は, 橋梁上 を走行している荷重が振動をせずに移動載荷により 生じる準静的な応力成分（以下，準静的応力）と, 振動する車両と橋梁の連成振動により生じる動的な 応力成分 (以下, 動的増幅応力) に分けられる. 動 的増幅率は, この準静的応力と動的増幅応力の振幅 比を表したものである.ここでは, 動的増幅率を DIF-1 として表記して式(1)から算出する.

$$
\text { DIF-1 }=\sigma_{I, d y, \text { max }} / \sigma_{s t, \text { max }}
$$

ここに， $\sigma_{s t, \text { max }}$ は準静的応力の最大值， $\sigma_{I, d y, \text { max }}$ は 図-8 に示すような $\sigma_{s t \text {, max }}$ を含む 1 サイクル中の動的 振幅 $\sigma_{d y}$ と静的振幅 $\sigma_{s t}$ の差の絶対值 $\sigma_{I, d y}=\left|\sigma_{d y}-\sigma_{s t}\right|$ の 最大をとったものである. 準静的応力は，モニタリ ングされた応答波形に対して, $1.0 \mathrm{~Hz}$ のローパスフ イルタ処理したものを用いた. $1.0 \mathrm{~Hz}$ に設定した理 由は, 卓越している $3 \mathrm{~Hz}$ の振動成分を概称除去で き, 実荷重と推定荷重との整合から最も適している ことを確認したためである.

\section{（5）実験結果}

各走行ケースにおいて得られた各車線の応力度波 形から平均して算出した動的増幅率の分子である動 的増幅応力, また, 分母である準静的応力およびそ れらの比をとった動的増幅率（DIF-1）をそれぞれ 図-9 (a)，図-9(b)および図-9 (c) にまとめた. 


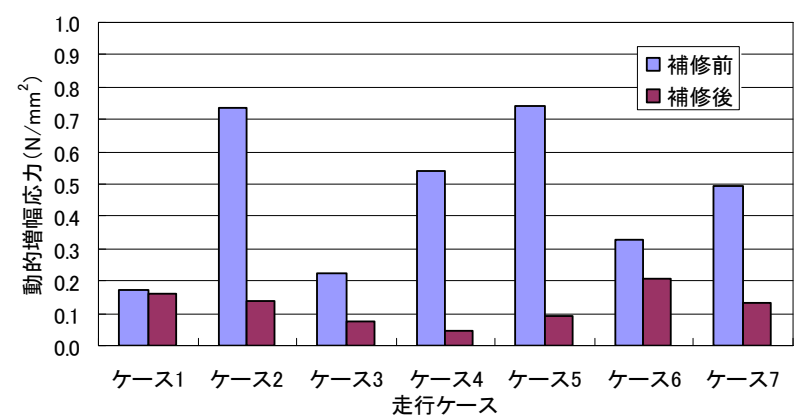

(a) 動的増幅応力

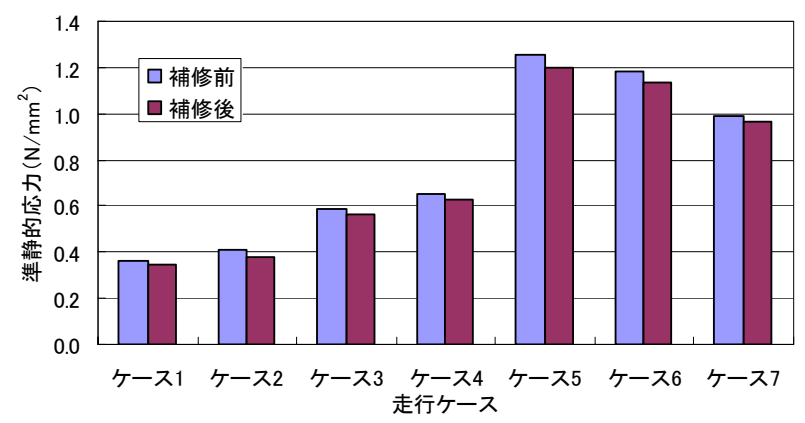

(b) 準静的応力

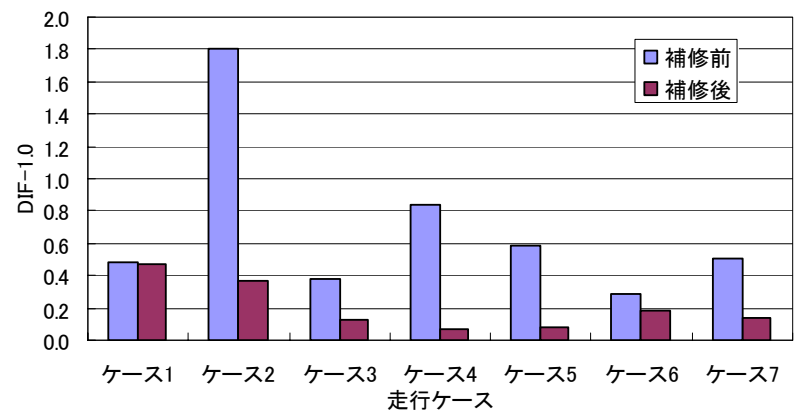

(c) 動的増幅率

図-9 各走行ケースにおける結果

動的増幅応力に着目した場合, 路面補修前の全ケ 一スの中で大きな值を示したケースは，図-9(a)に 示すように， 3 軸トラックが第 2 走行車線を走行し た場合（ケース 2）とセミトレーラが第 1 走行車線, 第 2 走行車線を 2 台で並走した場合（ケース 5) で あった. 走行ケース 2 は, ケース 5 に比べて準静的 応力 (図-9 (b) 参照) は $1 / 3$ 程度であるが， 3 軸卜 ラックが単独で第 2 走行車線を走行するケース 2 は, セミトレーラが並走するケース 5 の動的増幅応力と 同程度だった。

これらを動的増幅率で表現すると図-9 (c) のよう になり, ケース 5 は橋梁上に存在する車両の載荷荷 重による準静的応力の影響が大きくなり, 動的増幅 率としては 0.6 となった。 ケース 2 はケース 5 より 荷重が小さいため, 動的増幅率は 1.8 になった。す なわち, ケース 2 は準静的応力（図-9(b) 参照）の 1.8 倍もの動的増幅応力を有していることになる.

これに対して路面を補修した場合，ケース 2 とケ 一ス 5 の動的増幅応力は $0.1 \mathrm{~N} / \mathrm{mm}^{2}$ 程度になってお

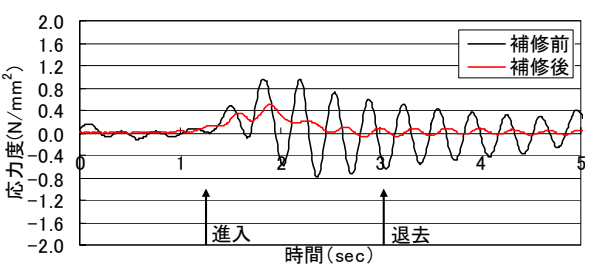

(a) ケース 2

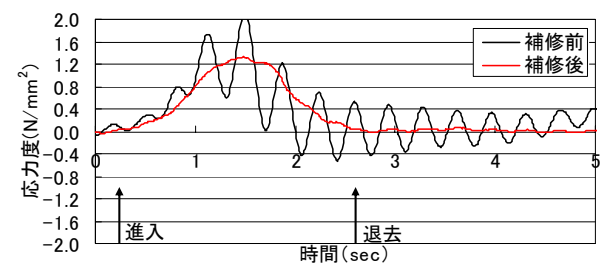

(b) ケース 5

図-10 応力度波形（測点: 第 2 走行車線下）

り, ケース 2 の動的増幅率は 0.4 程度, ケース 5 で は 0.1 程度まで低減した。これにより, 第 2 走行車 線の路面補修が橋梁の応力度の改善に大きく寄与し たことが明らかとなった。

このケース 2 とケース 5 における路面補修前後で の第 2 走行車線下で計測された応力度波形を図-10 に示寸. ケース 2 とケース 5 ともに, 路面補修前で は対象橋梁のたわみ 1 次振動と車両のばね上振動と の連成により約 $3 \mathrm{~Hz}$ の振動で大きく増幅している. また, 路面補修後はそれらの振動成分がかなり小さ くなり, 車両と橋梁との連成による増幅が改善され ている.

上述したケース 2 とケース 5 の次に動的応力振幅 （図-9 (a)参照）が大きかった走行ケースは，セミ トレーラ 1 台が第 2 走行車線を走行した場合（ケー ス 4）と 3 軸トラックが第 2 走行車線，セミトレー ラが第 1 走行車線を並走した場合（ケース 7）であ った. ケース 4 は, ケース 7 に比べて準静的応力が 4 割程度小さいが, ケース 4 とケース 7 の動的増幅 応力は, 同程度であり $0.5 \mathrm{~N} / \mathrm{mm}^{2}$ となっていた.

上述したケース 2，4，5および 7 の走行ケースは, 試験車が第 2 走行車線を走行することにより, 動的 な応力が増幅されていることが明らかとなった。ま た，その路面を補修したことによりはるかに振幅が 小さくなったことを確認した.

\section{6. 長期モニタリングの概要}

試験車を用いた走行実験では，既知の重量を有し た試験車が限定された走行速度で単独走行および並 列走行した。しかし, 実際に走行している一般の大 型車は，様々な走行速度，重量およびばね特性を有 して単独または複数台で並走もしくは連行してい 


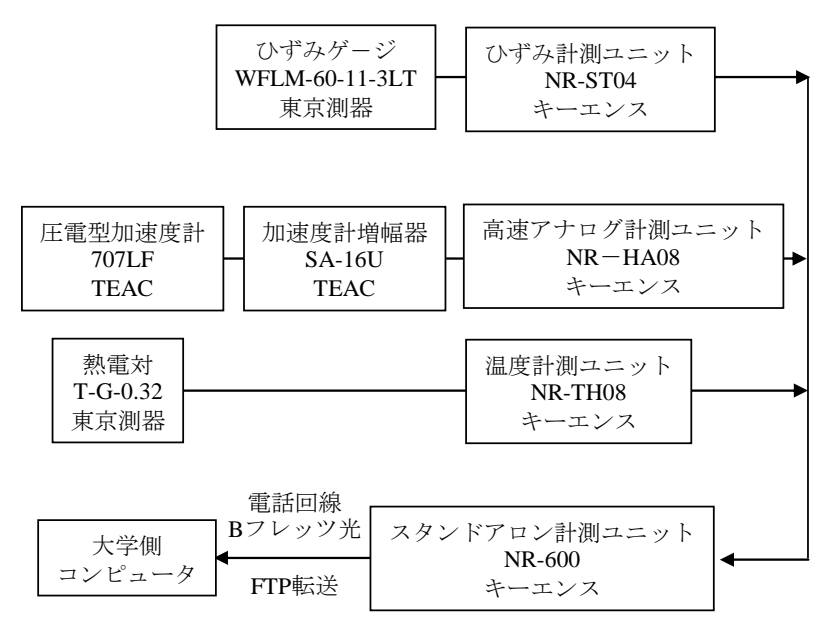

図-11 モニタリングに用いた機器の系統図

る. そのため, 日常の一般車走行時において, 主桁 がどの程度振動しているのかを監視する必要がある と考えた. また, 路面の補修により, それらの応答 がどの程度低減できたのか定量的に把握する必要が あると考えた。 そこで, 路面補修前後において, 一 般車を対象としたモニタリングを行った。

対象橋梁におけるモニタリング項目は，主桁断面 に着目したひずみ, 主桁の加速度および温度であ る.ひずみゲージ，加速度計および熱電対の測点配 置は，図-7に示した配置と同じである.

モニタリングに用いた機器の系統図を図-11 に示 す．本モニタリングでは，ひずみ，加速度および温 度データをそれぞれの機器を通して最終的にスタン ドアロン計測ユニット NR-600（キーエンス製）に 集約させ，電話回線（B フレッツ光）により大学の コンピュータヘデータを転送している.

これまでのモニタリングを用いた研究では, デー タの通信容量を小さくするために，計測現場におい て, 振動数や減衰定数などの必要な情報をリアルタ イムで分析し，その分析結果を携帯電話のインター ネット機能により転送する手法を用いたモニタリン グ実績 ${ }^{9}$ がある。 それに対して, 本研究では, デー 夕の通信容量が大きくなるが, 様々な分析が再度必 要になったときのために, 全時刻歴のデータを電話 回線により転送し，記録保存することにした。

また，これまでの橋梁振動に関するモニタリング 実績では, 振動数や減衰定数などの固有振動特性の 推移を観測した研究 ${ }^{10)}$ が多く, 応答值と外力との 関係を長期にわたり観測した事例 ${ }^{11)}$ は少ない。特 に, 路面補修前後での走行荷重と橋梁振動のモ二タ リングを長期にわたり行った研究はない.

本研究で行った路面補修前のモニタリング期間 は，2007 年 1 月 1 日〜2009 年 5 月 19 日までの約 2 年間 5 ケ月, 補修後のモニタリング期間は 2009 年
5 月 20 日〜2010 年 5 月 19 日までの約 1 年間とし た。時間間隔は $100 \mathrm{~Hz}$ で計測を行い，1 日のデータ 転送量は 360MB 程度（転送時間：20３0 分程度） である. 1 ファイルを 16384 個のデータ $(100 \mathrm{~Hz}$ サ ンプリング）とし，分割保存して，全時刻歴データ をモニタリングした。

\section{7. 走行荷重群の荷重推定}

加速度や応力度などの橋梁の応答值をモニタリン グする場合, 橋梁を加振する荷重を把握できれば, それらの 1 対 1 の対応を考察できる.

これまで, 様々な車両の軸重推定手法 ${ }^{11)-15)}$ が提 案されているが, 本研究では橋梁の振動モニタリン グとして, 大型車と連成振動を起こしている $3 \mathrm{~Hz}$ のたわみ 1 次振動を励起させる走行荷重を推定する 方法を考えた. 常時の交通状況は, 単独車両による 走行とは限らず, 並走や連行走行も考えられ, それ らの荷重により, たわみ 1 次振動を励起させている. そこで，本研究では，たわみに伴う曲げひずみから 橋梁上における走行荷重群の荷重を推定した。

\section{（1）推定手法}

本研究において用いた走行荷重群の荷重推定方法 は，たわみ変形を生じる曲げひずみを計測すること により, 橋梁を一つの量りとして, 走行荷重を推定 するものである（図-12 参照）。ひずみ計測点（3 地点, 図-7 参照) は, 主桁支間中央における各車 線（第 1 走行, 第 2 走行, 追越）の左車輪位置にあ り，主桁におけるひずみ值をこの 3 箇所の主桁ひず みで代表させている.

計測されるひずみ波形は，振動成分が含まれてい るため, $1.0 \mathrm{~Hz}$ のローパスフィルタを施し, 動的成 分を除去して準静的な時刻歴ひずみ波形を作成する. このフィルター処理された 3 地点の時刻歴ひずみ波 形を足し合わせ，その波形に対して換算係数を掛け ることにより, 橋梁上に存在する走行荷重群を時刻 歴波形のまま推定する簡易なものである.ここで, 推定される走行荷重群は, たわ久変形に伴い生じる 支間中央のひずみ波形を形成する荷重群であり, 単 独走行とは限らない。

一例として, 図-12 のように, 追越車線に 3 軸卜 ラック, 第 1 走行車線にセミトレーラが走行してい るときの各車線下のひずみ波形 $(1.0 \mathrm{~Hz}$ のローパス フィルタを施したもの）とそれらを足し合わした波 形を図-13 (a)に示寸。これに換算係数を掛け合わせ た荷重波形を図-13(b) に示す.このように並走した 


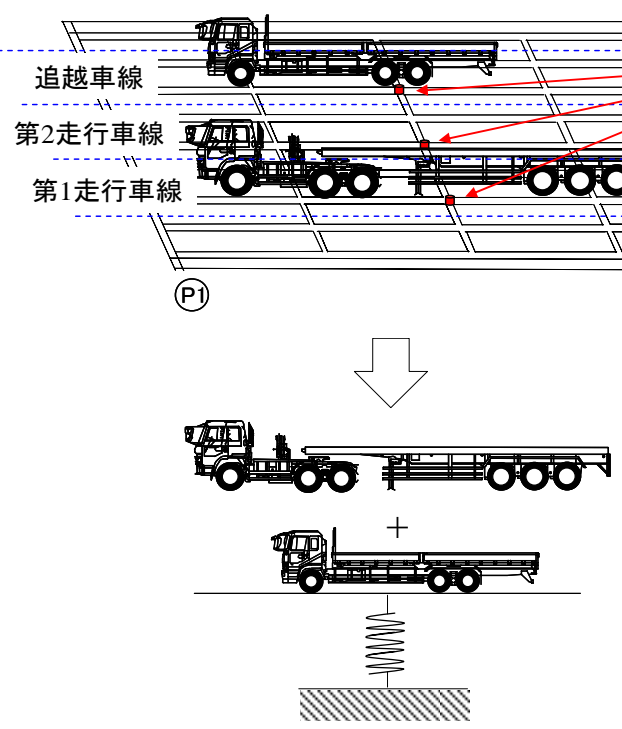

図-12 走行荷重の推定方法の概念図

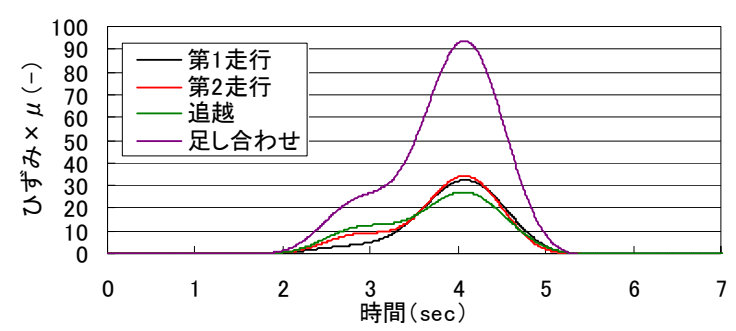

（a）各測点のひずみと足し合わせ波形

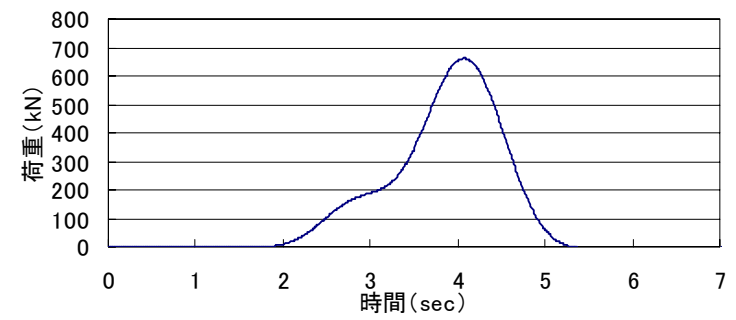

（b）重ね合わせ波形に換算係数を掛けた荷重推定波形

図-13 走行荷重の推定方法

場合, 4sec 付近の大きな振幅がこれらの荷重とし て記録される，なお，車軸長や走行速度の違いによ り，大きな 1 つの振幅を有した山型の波形にはなら ない場合があるが, その場合, 極值を調心゙, 極大值 となっていれば荷重の振幅として記録した。この例 の場合, 3sec 付近にも小さな荷重振幅が見られる が，極值を調べた結果，極值になっていなかったた め, 1 つの走行荷重として記録した. また, 並走や 車両間隔などの関係から 2 つの極值をとった場合は, それぞれの極值を走行荷重として記録した。

この手法を用いることにより, どの程度の軸重を 有した車両が，ぞの車線を，どの程度の車間間隔で 走行しているのかを追及することなく, たわみに伴 う曲げ振動を生じさせる走行荷重群を推定すること ができる.
表-3 試験車の実荷重と推定荷重（単位: $\mathrm{kN}$ )

（a）各試験車の実荷重

\begin{tabular}{|c|c|r|r|}
\hline \multicolumn{2}{|c|}{} & 補修前 & 補修後 \\
\hline \multirow{2}{*}{$\mathrm{T} 1$ (トラクタ $)$} & 前輪 & 65.76 & 67.33 \\
\cline { 2 - 4 } & 後輪合計 & 98.59 & 94.57 \\
\hline T1(セミトレ-ラ) & 3軸合計 & 247.25 & 248.43 \\
\hline \multirow{2}{*}{ T2(トラクタ) } & 前輪 & 64.39 & 62.92 \\
\cline { 2 - 4 } & 後輪合計 & 163.56 & 160.13 \\
\hline T2(セミトレ-ラ) & 軸合計 & 186.30 & 191.20 \\
\hline \multirow{2}{*}{ T3(トラクタ) } & 前輪 & 63.41 & 62.33 \\
\cline { 2 - 4 } & 後輪合計 & 159.05 & 159.94 \\
\hline T3(セミトレ-ラ) & 3軸合計 & 192.86 & 191.88 \\
\hline \multirow{2}{*}{$\mathrm{T} 4(3$ 軸トラック) } & 前輪 & 72.13 & 57.82 \\
\cline { 2 - 5 } & 後輪合計 & 170.03 & 182.57 \\
\hline
\end{tabular}

（b）各走行ケースにおける実荷重と推定荷重

\begin{tabular}{|c|c|c|c|c|c|c|c|}
\hline \multirow{2}{*}{$\begin{array}{c}\text { 走行 } \\
\text { ケース }\end{array}$} & & \multicolumn{3}{|c|}{ 補修前 } & \multicolumn{3}{|c|}{ 補修後 } \\
\hline & & 推定荷重 & 実荷重 & 誤差 & 推定荷重 & 実荷重 & \begin{tabular}{|l|} 
誤差 \\
\end{tabular} \\
\hline \multirow{3}{*}{ ケース7 } & \multirow{3}{*}{$\mathrm{T} 1+\mathrm{T} 4$} & 677.70 & 653.76 & 0.04 & 656.26 & 650.72 & 0.01 \\
\hline & & 667.97 & 653.76 & 0.02 & 661.48 & 650.72 & 0.02 \\
\hline & & & & & 655.48 & 650.72 & 0.01 \\
\hline \multirow{5}{*}{ ケース 5,6 } & \multirow{5}{*}{$\mathrm{T} 2+\mathrm{T} 3$} & 855.63 & 829.57 & 0.03 & 819.79 & 828.39 & \begin{tabular}{|c|}
-0.01 \\
\end{tabular} \\
\hline & & 795.24 & 829.57 & -0.04 & 823.25 & 828.39 & -0.01 \\
\hline & & 856.12 & 829.57 & 0.03 & 772.03 & 828.39 & $\begin{array}{l}-0.07 \\
\end{array}$ \\
\hline & & 807.59 & 829.57 & -0.03 & 807.23 & 828.39 & -0.03 \\
\hline & & 812.59 & 829.57 & \begin{tabular}{|c|}
-0.02 \\
\end{tabular} & 771.18 & 828.39 & $\begin{array}{l}-0.07 \\
\end{array}$ \\
\hline \multirow{4}{*}{ ケース 3,4} & \multirow{4}{*}{ T1 } & 398.04 & 411.60 & -0.03 & 383.93 & 410.33 & -0.06 \\
\hline & & 438.40 & 411.60 & 0.07 & 423.86 & 410.33 & 0.03 \\
\hline & & 437.06 & 411.60 & 0.06 & 431.20 & 410.33 & 0.05 \\
\hline & & & & & 420.69 & 410.33 & 0.03 \\
\hline \multirow{10}{*}{ ケース 1,2} & \multirow{10}{*}{$\mathrm{T} 4$} & 246.85 & 242.16 & 0.02 & 238.78 & 240.39 & $\begin{array}{l}-0.01 \\
\end{array}$ \\
\hline & & 269.50 & 242.16 & 0.11 & 257.01 & 240.39 & 0.07 \\
\hline & & 285.30 & 242.16 & 0.18 & 262.59 & 240.39 & 0.09 \\
\hline & & 247.07 & 248.92 & -0.01 & 238.74 & 240.39 & -0.01 \\
\hline & & 251.99 & 248.92 & 0.01 & & & \\
\hline & & 281.92 & 248.92 & 0.13 & & & \\
\hline & & 263.41 & 248.92 & 0.06 & & & \\
\hline & & 406.72 & 421.40 & -0.03 & & & \\
\hline & & 450.04 & 421.40 & 0.07 & & & \\
\hline & & 450.74 & 421.40 & 0.07 & & & \\
\hline
\end{tabular}

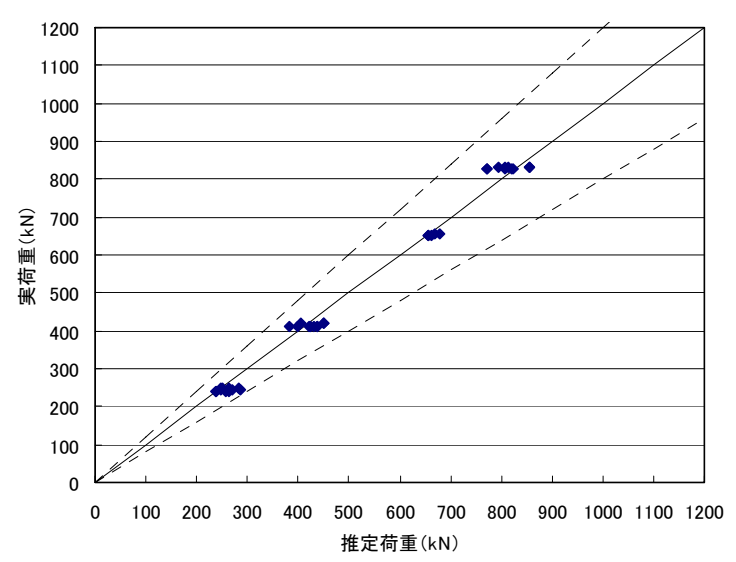

図-14 実荷重と推定荷重の関係

\section{（2）推定精度}

試験車走行実験に用いた各試験車の実荷重を表3 (a) に示す。また，実験では様々な組み合わせで走 行実験（図-6 参照）を行っており, それらの車両 の組み合わせによる走行荷重群としての実荷重と推 定荷重の比較を表-3(b)にまとめた. 図-14 は, 表3 (b) をグラフ上にプロットしたものである。なお, 図中の点線は $\pm 20 \%$ 示す. 
5 章で述べたように, 補修前の 3 軸トラック（試 験車 T4）が走行した時のみ車両と橋梁との連成振 動が大きかったため, それらの影響が多少見られた が, 相関係数は 0.9957 となっており, 十分な精度 があると判断した. また, 各試験車の組み合わせに より， 4 パターンの走行荷重群を作成したところ, $800 \mathrm{kN}$ 程度の大きな荷重に対しても十分推定でき, 実荷重と推定荷重には線形関係が成り立っているこ とがわかった.

そこで，ひずみ值から荷重一の換算係数は，これ らの試験車走行による結果から $7.055 \mathrm{kN} / \mu$ とした. 本研究では 3 箇所のひずみ波形を単純に足し合わせ ているが, 平均させた場合でも換算係数を変えるだ けで推定が可能である. 以後, 走行荷重群としての 荷重のことを載荷荷重と呼ぶことにする.

\section{8. 路面の補修前後におけるモニタリング}

対象橋梁は 3 車線を有しており，2007，2008 お よび 2009 年の年平均日交通量は 45293，36308 およ び 36192 台/日, 大型車混入率は 37, 34 および $29 \%$ の非常に交通量の多い状況である. そこで, 普 通車も含めたすべての車両を評価対象にするのでは なく, 対象橋梁に大きな加振力を与える大型車両に よる走行荷重群の荷重（たわみに伴う曲げ振動を生 じさせる橋梁上での載荷荷重）を評価対象にするこ とにした，そのため, 本研究では, 載荷荷重 $100 \mathrm{kN}$ 以上の大型車を確実に評価できるようするため, 各 車線で計測されたひずみ $5 \mu$ 以上（応力 $0.155 \mathrm{~N} / \mathrm{mm}^{2}$ 以上）の值を分析対象とした.

\section{（1）卓越振動数と減衰定数}

対象橋梁の支間中央では, たわみ 1 次振動, ねじ り 1 次振動に加えて $10 \mathrm{~Hz}$ 付近に高次モードの卓越 振動を確認できたが, 常時では, 大型車両との連成 振動により, たわみ 1 次振動の $3 \mathrm{~Hz}$ が大きく卓越 していた.

そこで本研究では, $3 \mathrm{~Hz}$ 付近のたわみ 1 次振動に 着目し, その振動数と減衰定数の関係を路面の補修 前後 1 年ずつまとめたものを図-15 に示す.

このデータは, 橋梁上に載荷荷重がない 2 秒以上 の減衰自由振動波形 (支間中央の追越車線側の加速 度（図-7 参照））に対して $\mathrm{ERA}^{16)}(100 \mathrm{~Hz}$ サンプ リングのデータから少なくとも 200 個以上のデータ を用いてハンケル行列を作成し，その行と列のサイ ズを $3: 1$ とした。）を用いて卓越振動数および減 衰定数を算出したものであり，1 日に 8 回，3 時間

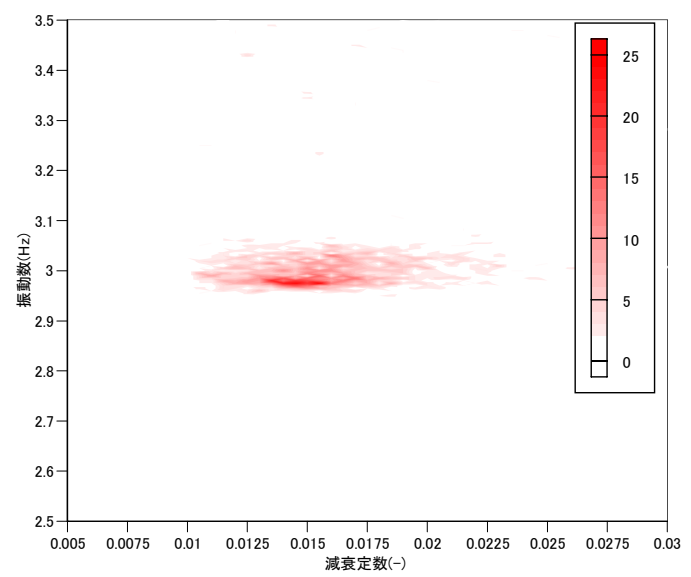

(a) 補修前

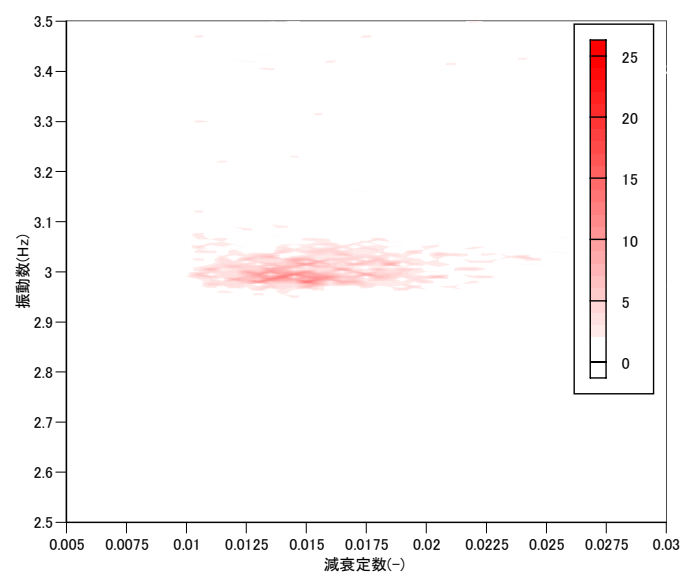

(b) 補修後

図-15 たわみ 1 次振動の卓越振動数とモード減衰定数

に 1 回ずつ分析を行った. 図中の濃淡色は, 振動数 を分解能 (分割間隔) $0.005 \mathrm{~Hz}$, 減衰を分解能 0.0005 に分割し, モニタリングした振動数と減衰の 組み合わせを上記の分割した区分ごとにカウントし たものである.

これより, たわみ 1 次振動は, 補修前において振 動数 $2.975 \mathrm{~Hz}$ （平均 $3.009 \mathrm{~Hz}$, 標準偏差 $0.08 \mathrm{~Hz}$ ), 減衰定数 $0.0145 \sim 0.0155$ (平均 0.016 , 標準偏差 0.004）に最も多く分布していた。一方, 補修後で は, 振動数 $2.980 \mathrm{~Hz}$ (平均 $3.014 \mathrm{~Hz}$, 標準偏差 $0.09 \mathrm{~Hz}$ ), 減衰定数 0.015 (平均 0.017 , 標準偏差 0.004）に最も多く分布しており, 補修前後におい て振動特性の大きな変化は見られなかった.

また，試験車走行実験から補修前におけるたわみ 1 次振動の減衰定数は $0.018 \sim 0.022$, 補修後では 0.017〜0.025 となっていた. 常時のモニタリングに より得られた減衰定数は, 走行実験により得られた 減衰定数の下限側になっていた.

\section{（2）走行荷重群の荷重特性（載荷荷重特性）}

先に述べた荷重推定方法を用いて, 路面補修前 2 年 5 ケ月および補修後 1 年における日々の最大載荷 


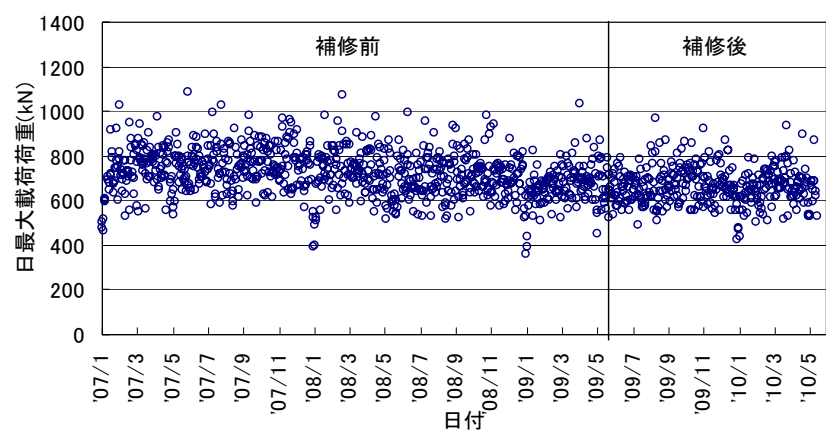

図-16 日最大載荷荷重

(補修前: 2 年 5 ケ月, 補修後: 1 年)

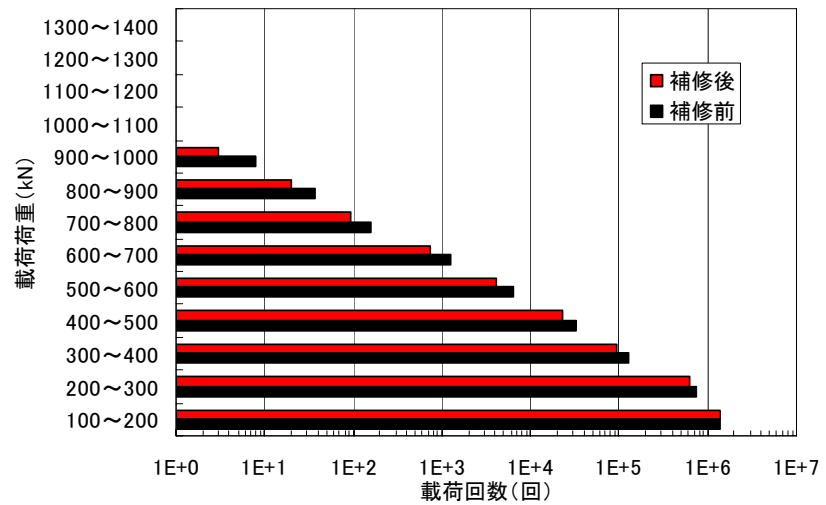

図-17 載荷荷重の頻度分布 (補修前: 1 年, 補修後: 1 年)

荷重を図-16にまとめた。

これより，たわみに伴う曲げひずみを与える 1 日 ごとの最大載荷荷重は，補修前後ともに概ね 500〜 $1000 \mathrm{kN}$ の範囲に分布している. 補修前の最大值は $1088 \mathrm{kN}$ ，補修後は $967 \mathrm{kN}$ であり，補修前の平均值 は $721 \mathrm{kN}$ ，補修後は $666 \mathrm{kN}$ であった。モニタリン グ期間に計測された最大載荷荷重は，設計活荷重の 半分程度となる $1150 \mathrm{kN}$ を超えていなかった.

つぎに，路面の補修前後 1 年ずつにおいて，載荷 荷重の頻度分布を図-17 にまとめた。これより，補 修前後 1 年ともに最も頻度の多い載荷荷重は，100 〜200kNであることがわかる，これは，単独による ものか，並走および連行によるものか明らかではな いが，大型車の空車または積載車の単独走行による ものと考えられる.また， 2 番目に頻度の多かった 載荷荷重は，200～300kN であり，245kN 車両など の積載車による分布と考えられる.

\section{（3）応力度}

5 章で述べた試験車走行実験において, 最大応力 度を記録したケースは，セミトレーラ 2 台が第 1 走 行車線および第 2 走行車線を並走した時（ケース 5）の第 2 走行車線の主桁下面で $2.0 \mathrm{~N} / \mathrm{mm}^{2}$ (図10 (b) 参照) であった。

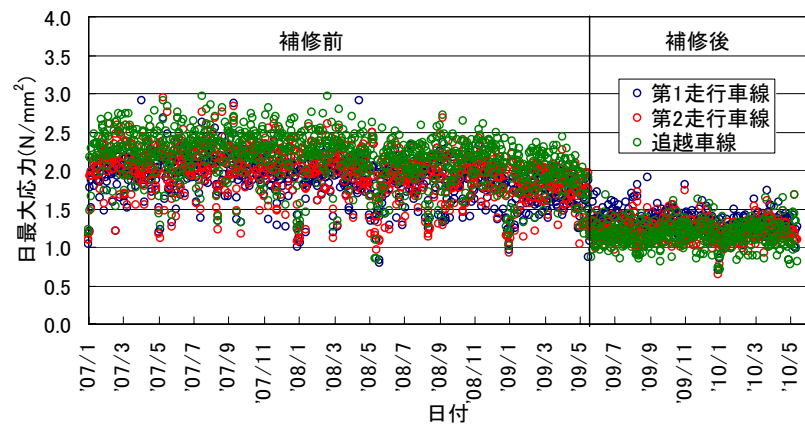

図-18 日々の最大応力度

(補修前: 2 年 5 ケ月, 補修後: 1 年)

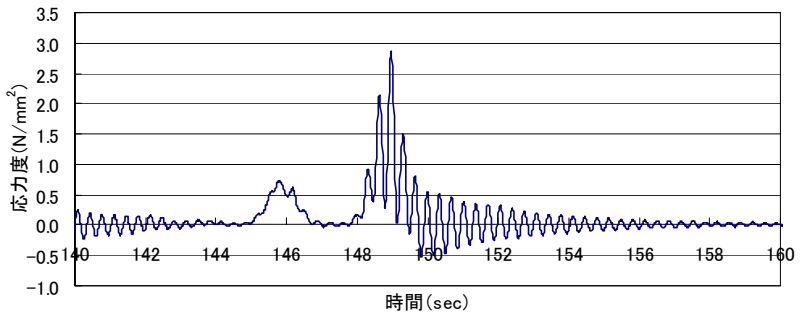

（a）応力度（第 1 走行車線）

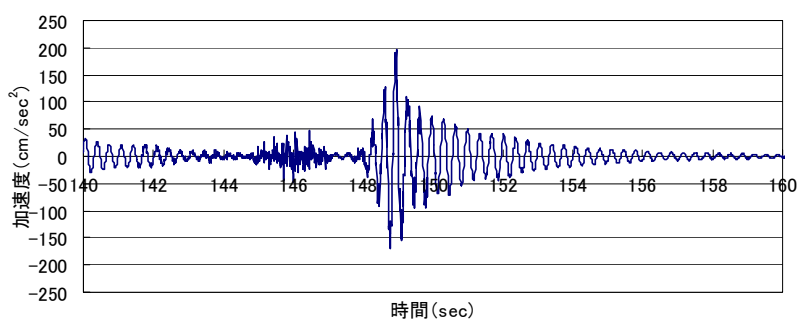

(b) 加速度（第 1 走行車線）

図-19 最大応力度を観測した時の応答波形

これに対して, 路面補修前 2 年 5 ケ月および補修 後 1 年において得られた, 1 日ごとの主桁下面の最 大応力度を図-18 に示す.

補修前 2 年 5 ケ月の結果から, 日最大応力度の最 大值（3 車線の平均）は $2.9 \mathrm{~N} / \mathrm{mm}^{2}$ であり, 日最大 応力度の平均值 (3 車線の平均) は $2.0 \mathrm{~N} / \mathrm{mm}^{2}$ であ った。概ねセミトレーラ 2 台並走による試験走行実 験の結果（図-10 (b) 参照）とこの平均值が一致して いた.

一方, 補修後 1 年の結果から, 日最大応力度の最 大值（3 車線の平均）は $1.8 \mathrm{~N} / \mathrm{mm}^{2}$ 程度であり, 日 最大応力度の平均值（3 車線の平均）は $1.2 \mathrm{~N} / \mathrm{mm}^{2}$ 程度であった. 補修前後の平均值で比較すると補修 により日最大応力度は 40\%低減している.

最大応力度を記録した一例として，2007 年 9 月 12 日, 5 時 41 分に第 1 走行車線において観測され た応答波形を図-19 に示す。これより，応力度 $3.0 \mathrm{~N} / \mathrm{mm}^{2}$, 加速度 $200 \mathrm{~cm} / \mathrm{sec}^{2}$ の振幅が記録されて 


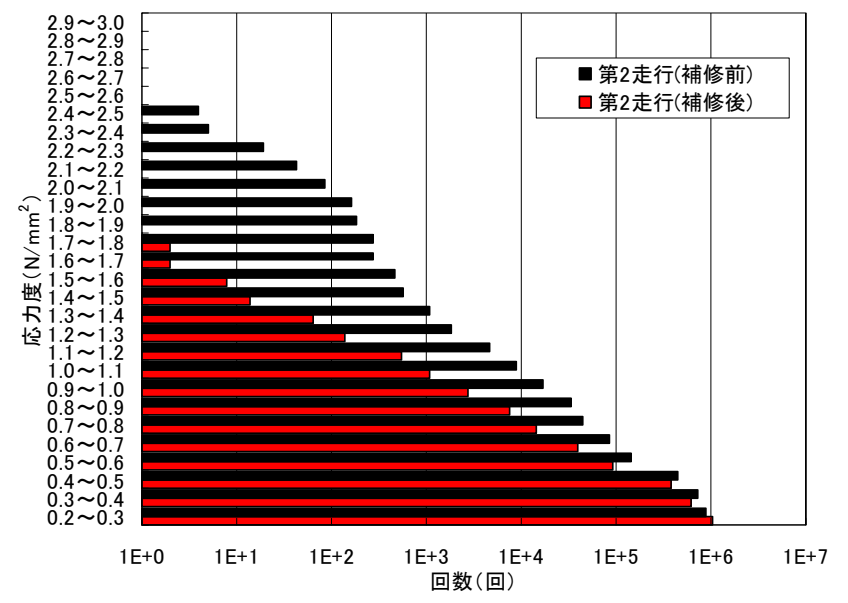

図-20 応力度の頻度分布 (補修前: 1 年, 補修後: 1 年)

おり，いずれも $3.0 \mathrm{~Hz}$ のたわみ 1 次振動により主桁 の振動振幅が大きく増幅している.このときの推定 載荷荷重は $984.4 \mathrm{kN}$ であり, 比較的重量の重い載荷 荷重により加振された結果として生じたものである.

つぎに，第 2 走行車線を対象として，路面補修前 後 1 年ずつの各応力振幅の頻度分布を図-20にまと めた。 これより, 補修前後ともに頻度の多かった応 力度振幅は $0.2 \sim 0.3 \mathrm{~N} / \mathrm{mm}^{2}$ であった. 路面補修後で は $1.8 \mathrm{~N} / \mathrm{mm}^{2}$ 以上の応力振幅が発生しておらず, 補 修前に比べて応力振幅 $0.2 \sim 0.3 \mathrm{~N} / \mathrm{mm}^{2}$ の頻度が増加 していた.

以上のモニタリング結果を踏まえて, 設計の観点 から考察する. 対象橋梁は, TT-43 荷重に対して許 容応力度法で設計されており, 詳細設計の計算結果 から, 活荷重によって生じる主析下縁の応力度は約 $6.6 \mathrm{~N} / \mathrm{mm}^{2}$ である. 補修前のモニタリング期間中の 最大応力度および日最大応力度の平均值は, $3.0 \mathrm{~N} / \mathrm{mm}^{2}$ および $2.0 \mathrm{~N} / \mathrm{mm}^{2}$ であり, 設計時の活荷重 による応力度の約半分程度および約 $1 / 3$ 程度であっ た。したがって, 設計の観点からは, 特に問題ない と判断した。 しかし，このような路面による応力度 の増幅は, 対象橋梁特有の結果ではなく, 他の橋梁 でも起こり得るものであるため, 注意が必要である.

このような事象をモニタリングする場合, 交通状 況による傾向を把握するだけであれば，交通量との 関係から, 短くて 1 週間程度, 温度による季節変動 を考慮するのであれば 1 年程度のモニタリングが必 要と考えられるが，今回のように異常振動を監視す ることを目的とする場合には 1 年以上の長期的な観 測が必要と考える.

\section{（4）動的増幅応力}

路面補修前 2 年 5 ケ月および補修後 1 年における 主桁下面での 1 日ごとの動的増幅応力の最大值を

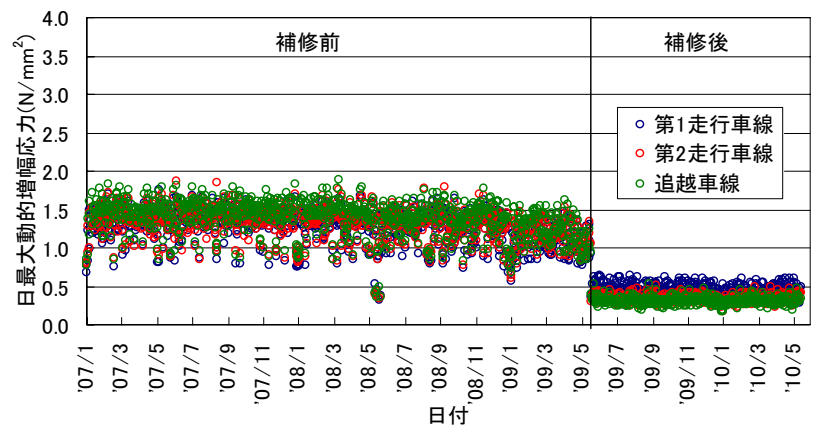

図-21 日々の最大動的増幅応力

(補修前: 2 年 5 ケ月, 補修後: 1 年)

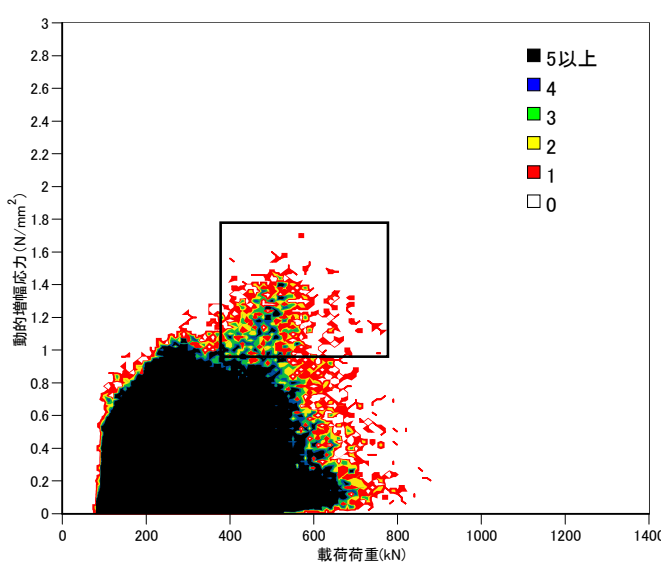

(a) 補修前（1 年分）

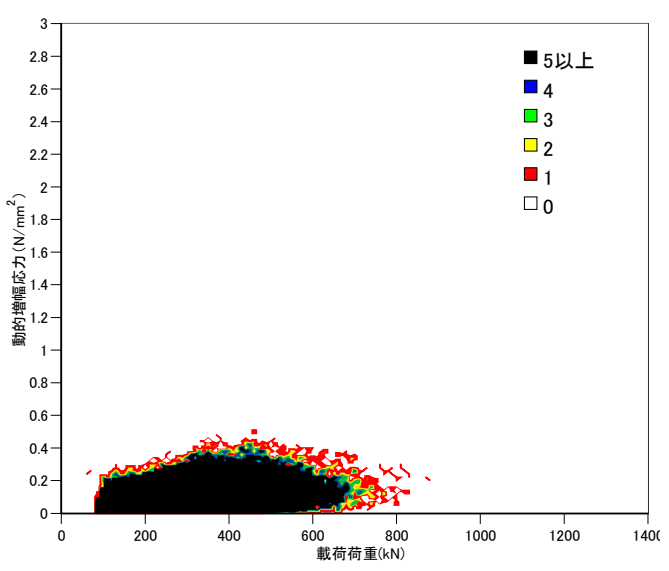

（b）補修後（1 年分）

図-22 動的増幅応力と載荷荷重の関係

図-21にまとめた.

補修前 2 年 5 ケ月のモニタリング結果から, 日最 大動的増幅応力の最大值および平均值（3 車線の平 均）は $1.84 \mathrm{~N} / \mathrm{mm}^{2}$ および $1.32 \mathrm{~N} / \mathrm{mm}^{2}$ であり, 補修 後 1 年の結果は, $0.56 \mathrm{~N} / \mathrm{mm}^{2}$ および $0.37 \mathrm{~N} / \mathrm{mm}^{2}$ であ った. 補修前後の平均值で比較すると日最大動的増 幅応力は補修により 70\%低減した。

つぎに，この日最大動的増幅応力を発生させた載 荷荷重との関係について調べるため, 補修前後 1 年 ずつの計測結果を図-22 に示す. なお, 図中の濃淡 
色は, 動的増幅応力を $0.02 \mathrm{~N} / \mathrm{mm}^{2}$ ごと, 載荷荷重 を $10 \mathrm{kN}$ ごとに分割して, 動的増幅応力と載荷荷重 との組み合わせによる頻度を上記の分割区分ごとに カウントしたものである.

これより, 補修前において, 日々の最大動的増幅 応力は, 400 800kN の載荷荷重（図-22（a）四角部 分参照）が大きな領域で大きな動的増幅応力が発生 していることが明らかとなった，図-19 で挙げた一 例のように, 比較的大きい荷重群の車両振動と周期 性路面および橋梁との連成振動により応力度が増幅 していたことになる.

これに対して路面補修後では, 車両と橋梁との連 成振動が小さくなり, 図-22(b)に示すように動的増 幅応力が大きく低減し, どの載荷荷重領域において も平均的な動的増幅応力になった.

\section{（5）動的増幅率}

動的増幅率 (DIF-1) ${ }^{8)}$ は動的増幅応力を準静的応 力で除し, 準静的応力の何倍が動的な応力として作 用しているのかを表すものであり, 載荷荷重が設計 活荷重相当であった場合, 設計で用いる衝撃係数の 意味をもつことになる.

路面の補修前 2 年 5 ケ月および補修後 1 年におい て, 1 日ごとの動的増幅率（DIF-1）の最大值をプ ロットしたものを図-23 に示寸。これより，路面補 修前の各車線の最大值は 5.5 5.9, 平均值は 3.5 3.7 であった. 一方, 路面補修後の各車線の最大值 は 1.8〜2.0, 平均值は 0.9〜1.0であった.

つぎに，この動的増幅率を生じさせた載荷荷重を 調べるために, 路面補修前後 1 年ずつにおける載荷 荷重と動的増幅率（DIF-1，第 2 走行車線下のひず みから算出）の関係を調べ, 図-24 に示した。なお, 図中の濃淡色は, 動的増幅率を 0.1 ごと, 載荷荷重 を $10 \mathrm{kN}$ ごとに分割して, 動的増幅率と載荷荷重と の組み合わせによる頻度を上記の分割区分ごとにカ ウントしたものである.

これより, 補修前後において, 日々の動的増幅率 として最も頻度が多かった載荷荷重と動的増幅率の 組み合わせは, 補修前において載荷荷重 $170 \mathrm{kN}$, 動 的増幅率 0.2 , 補修後において載荷荷重 $170 \mathrm{kN}$, 動 的増幅率 0.1 であった。

つぎに，図-25に示すように，図-24における載 荷荷重や動的増幅率が大きい領域で, 頻度の少ない 分布域に着目した. この図から, 補修前後ともに各 載荷荷重における動的増幅率（DIF-1）の最大值 は, 載荷荷重が大きくなるにつれて小さくなる右下 がりの反比例の関係になっている.

図-22 で示したように，3Hz 付近に後輪ばね上振

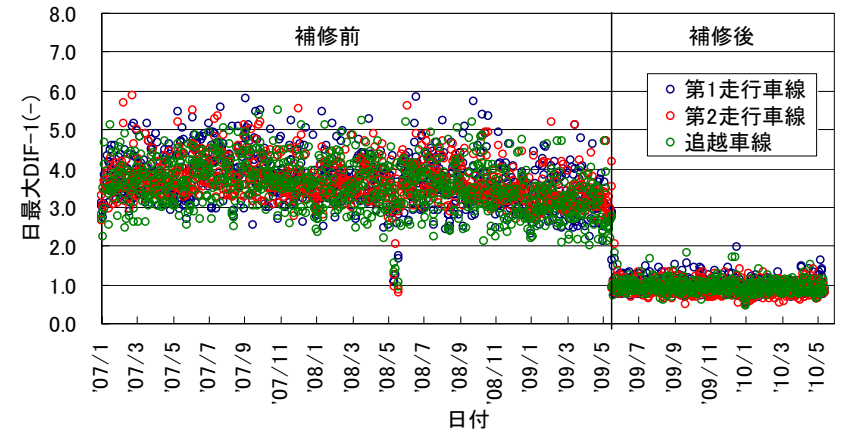

図-23日々の最大動的増幅率 (DIF-1)

(補修前: 2 年 5 ケ月, 補修後: 1 年)

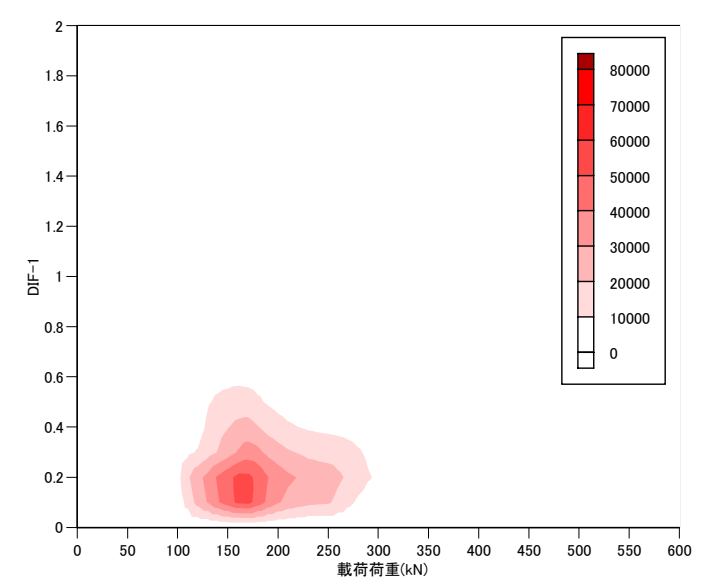

（a）補修前（1 年分）

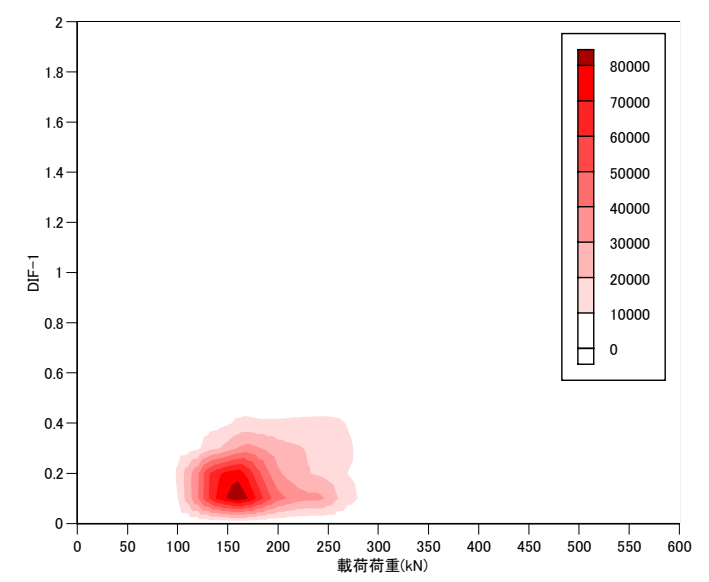

(b) 補修後（1 年分）

図-24 動的増幅率（DIF-1）之載荷荷重 $(0-600 \mathrm{kN})$

動を有した，400～800kN の走行荷重群により，車 両, 周期性路面および橋梁の連成振動が生じ, 主桁 において大きな動的増幅応力が発生していた。 しか しながら, 準静的応力で除した図-25 の動的増幅率 で見た場合, 各載荷荷重における動的増幅率（DIF1）の最大值は右下がりの分布になっていることか ら, 動的増幅率の分母にあたる準静的応力, 寸なわ ち, 橋梁上に存在する走行荷重群の載荷荷重の影響 が大きいことがわかる.

また, 路面補修前後ともに $800 \mathrm{kN}$ 付近 (図中黒 


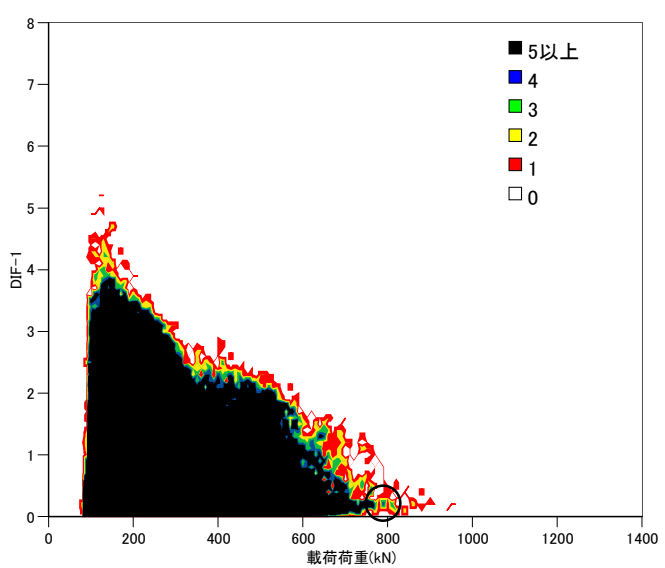

(a) 補修前（1 年分）

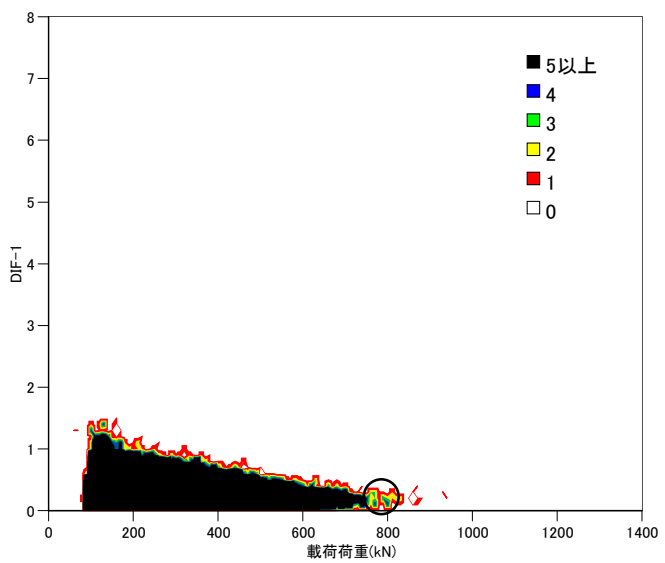

(b) 補修後（1 年分）

図-25 動的増幅率（DIF-1） と載荷荷重 $(0-1400 \mathrm{kN})$

丸部分）では動的増幅率（DIF-1）が $0.0 \sim 0.2$ に多 く分布していることから, 周期性路面の影響よりも 上述した走行荷重群の載荷荷重の影響の方が大きい ことがわかる。 寸なわち, 周期性路面の影響が橋梁 に対して大きくても動的増幅率の観点から見ると， 橋梁の動的応答は, 橋梁上に存在する走行荷重群の 載荷荷重に支配されている.

対象橋梁に対して長期モニタリングを実施した結 果, 周期性路面を有した橋梁が大きな振動を生じて いても主桁が受ける動的な影響としては, 設計衝撃 係数 0.16 (L:荷重, $10 /(25+37.47)=0.16 ）$ を考慮して いれば問題ないことが明らかになった.

\section{9. 振動解析}

周期性を有した路面が橋梁に与える動的な影響と して, 路面凹凸の波長と車両の走行速度をパラメー タとした振動解析を行うことにより, 主栴の動的増 幅率に対する路面凹凸の波長と車両の走行速度との 関係を明らかにする。

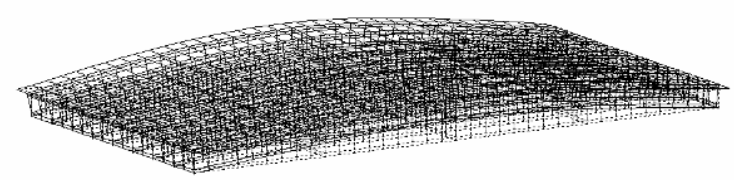

（a）たわみ 1 次振動 $2.9 \mathrm{~Hz}$

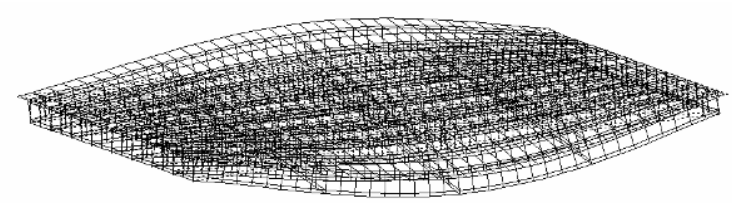

(b) ねじり 1 次振動 $3.4 \mathrm{~Hz}$

図-26 振動モード図

\section{（1）固有振動解析}

解析モデルは，斜角を忠実にモデル化し，床版を シェル要素, 主桁と中間横桁のウェブをシェル要素, 下フランジを梁要素とした。 なお, 各要素部材での 中立軸のくい違いは，剛部材を用いて考慮した。地 覆, 壁高欄は, 梁要素でモデル化し, 剛性および質 量を考慮した。また, 舗装の剛性は無視し, 質量の み考慮した。 支承条件としては, 現橋のゴムパッド 支承を考慮し, 橋軸方向の可動側 (P1 側) $3.43 \times 10^{5} \mathrm{kN} / \mathrm{m}$ ，固定側 (A2 側) $3.43 \times 10^{7} \mathrm{kN} / \mathrm{m}$ の ばねでモデル化した。また，橋軸まわりおよび橋軸 直角軸まわりに関する回転は可動とした。

つぎに，解析モデルにおける固有振動特性の妥当 性を調べるために, 固有振動解析を行った. 固有振 動解析の結果から得られた振動モード図を図-26に 示す.たわみ 1 次振動数は $2.9 \mathrm{~Hz}$ ，㸚じり 1 次振動 数は $3.4 \mathrm{~Hz}$ の結果を得た. これより, 実測の振動数 (たわみ 1 次振動数: $2.9 \sim 3.0 \mathrm{~Hz}$, ねじり 1 次振動 数：3.4〜3.6Hz）に近い值を得ることができ，実橋 を表現できる解析モデルを構築できた.

\section{（2）車両走行シミュレーション}

車両走行シミュレーションでは, Newmark $\beta$ 法 （時間間隔 $0.01 \mathrm{sec}, \beta=1 / 4$ ）による直接積分法を用 いて各測点の応答值を算出した。減衰は, 走行実験 において得られた，たわみ 1 次振動およびねじり 1 次振動の振動数とそれらのモード減衰定数としてそ れぞれ 2\%を用いて Rayleigh 減衰を仮定した。

車両モデルは，図-27 に示すようにリーフサスペ ンションを有した 3 軸トラックの試験車両をモデル 化した．また，この車両モデルの諸元を表-4にま とめた.

解析值の妥当性を確認するため, 実験と同じよう に第 2 走行車線を 3 軸トラックの試験車が $80 \mathrm{~km} / \mathrm{h}$ で走行したときの補修前後における応力度波形（第 


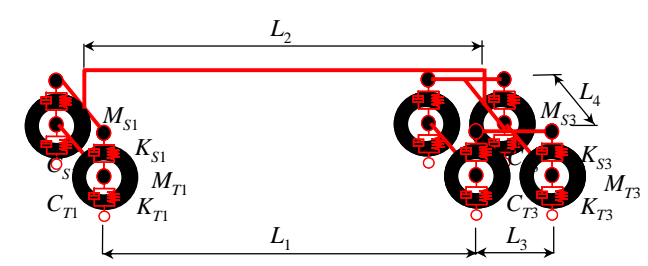

図-27車両モデル

表-4 車両モデル（試験車両）の諸元

\begin{tabular}{|c|c|c|c|c|}
\hline & 項目 & 記号 & 単位 & 数值 \\
\hline \multirow{5}{*}{ 全 } & 車両総重量 & & $\mathrm{kN}$ & 248.92 \\
\hline & 前輪-後輪前軸間 & $L_{1}$ & $\mathrm{~m}$ & 5.83 \\
\hline & 前輪-後輪中心間 & $L_{2}$ & $\mathrm{~m}$ & 6.49 \\
\hline & 後輪後軸間 & $L_{3}$ & $\mathrm{~m}$ & 1.32 \\
\hline & 左右車輪間 & $L_{4}$ & $\mathrm{~m}$ & 1.94 \\
\hline \multirow{8}{*}{$\begin{array}{l}\text { 前 } \\
\text { 輪 }\end{array}$} & ばね上質量 & $M_{S 1}$ & $\mathrm{kN} /\left(\mathrm{m} / \mathrm{sec}^{2}\right)$ & 3.26 \\
\hline & ばね上ばね定数 & $K_{S_{1}}$ & $\mathrm{kN} / \mathrm{m}$ & 441.00 \\
\hline & ばね上減衰係数 & $C_{S_{1}}$ & $\mathrm{kN} /(\mathrm{m} / \mathrm{sec})$ & 2.94 \\
\hline & ばね上振動数 & & $\mathrm{Hz}$ & 1.74 \\
\hline & ばね下質量 & $M_{T 1}$ & $\mathrm{kN} /\left(\mathrm{m} / \mathrm{sec}^{2}\right)$ & 0.73 \\
\hline & ばね下ばね定数 & $K_{T 1}$ & $\mathrm{kN} / \mathrm{m}$ & 3430.00 \\
\hline & ばね下減哀係数 & $C_{T 1}$ & $\mathrm{kN} /(\mathrm{m} / \mathrm{sec})$ & 9.80 \\
\hline & ばね下振動数 & & $\mathrm{Hz}$ & 11.61 \\
\hline \multirow{8}{*}{$\begin{array}{l}\text { 後 } \\
\text { 輪 }\end{array}$} & ばね上質量 & $M_{S 2}, M_{S 3}$ & $\mathrm{kN} /\left(\mathrm{m} / \mathrm{sec}^{2}\right)$ & 3.41 \\
\hline & ばね上ばね定数 & $K_{S_{2}}, K_{S 3}$ & $\mathrm{kN} / \mathrm{m}$ & 1666.00 \\
\hline & $\begin{array}{l}\text { ばね上減衰係数 } \\
\end{array}$ & $C_{S 2}, C_{S 3}$ & $\mathrm{kN} /(\mathrm{m} / \mathrm{sec})$ & 5.88 \\
\hline & ばね上振動数 & & $\mathrm{Hz}$ & 2.84 \\
\hline & ばね下質量 & $M_{T 2}, M_{T 3}$ & $\mathrm{kN} /\left(\mathrm{m} / \mathrm{sec}^{2}\right)$ & 0.95 \\
\hline & ばね下ばね定数 & $K_{T 2}, K_{T 3}$ & $\mathrm{kN} / \mathrm{m}$ & 3430.00 \\
\hline & ばね下減衰係数 & $C_{T 2}, C_{T 3}$ & $\mathrm{kN} /(\mathrm{m} / \mathrm{sec})$ & 9.80 \\
\hline & ばね下振動数 & & $\mathrm{Hz}$ & 11.85 \\
\hline
\end{tabular}

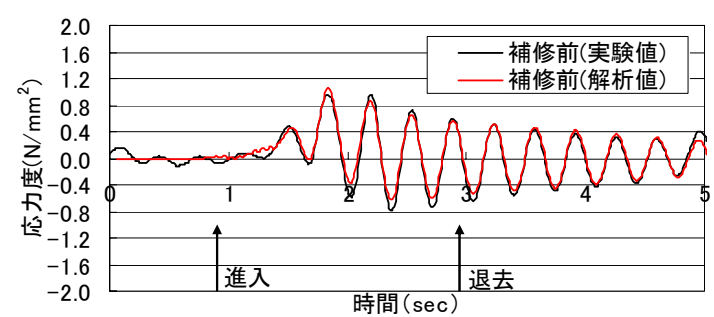

(a) 補修前

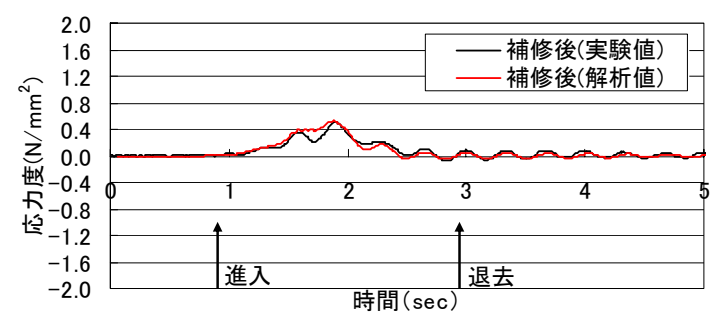

(b) 補修後

図-28 実験と解析の応力度

2 走行車線下）を実験と解析で比較し, 図-28 に示 した。なお，この際に用いた路面凹凸は，図-4に 示した実橋での補修前後における第 2 走行車線の路 面凹凸データを用いた。

これより，実橋の応力状態を再現できたことから， 実際の路面凹凸を用いて本シミュレーションを行う ことにより, 橋梁振動および車両振動の再現が可能 となった。また，路面凹凸の波長による影響を解析 上で検討することができる.

実橋では，伸縮継手近傍の路面凹凸の周期性の影

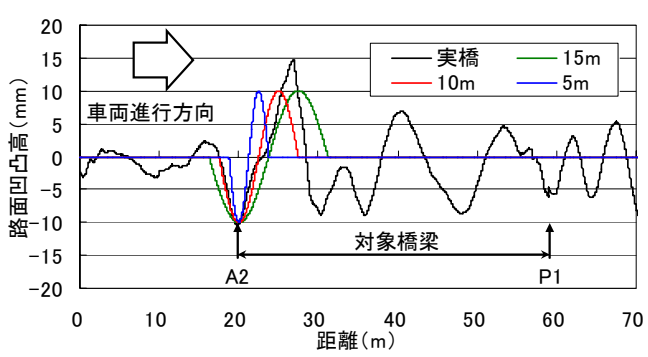

図-29 ジョイント近傍の路面のモデル化 （例：波長 $5 \mathrm{~m}, 10 \mathrm{~m}, 15 \mathrm{~m}$ の場合）

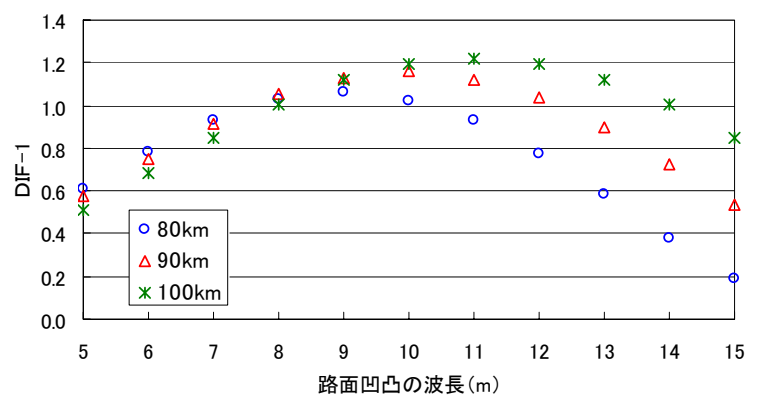

図-30 路面凹凸の波長と動的増幅率の関係

響が大きく，この伸縮継手近傍の路面凹凸により加 振された車両と橋梁との連成振動が問題となってい たことから, 解析上では伸縮継手近傍における路面 凹凸のみをモデル化し，その波長および車両の走行 速度を変化させて車両走行シミュレーションを行う ことにした。

路面凹凸のモデル化は, 実測された第 2 走行車線 の路面凹凸をもとにして図-29 に示すように伸縮継 手近傍のみモデル化し, その波長を 5～15m まで $1 \mathrm{~m}$ ずつ変化させた，なお，車両の走行速度により， 応答特性が変化するものと考えられ, 車両モデルの 走行速度は $80,90,100 \mathrm{~km} / \mathrm{h}$ の 3 ケースで解析を 行った。 その結果として, 支間中央の第 2 走行車線 下の応力度から得られた動的増幅率を図-30 に示寸.

これより, ジョイント近傍のみをモデル化した路 面凹凸であるが，その波長を 5 15m まで $1 \mathrm{~m}$ ずつ 変化させたところ走行速度 $80 \mathrm{~km} / \mathrm{h}$ では波長 $9 \mathrm{~m}$ を 最大として波長 8〜10m で動的増幅率が 1.0 程度, 走行速度 $90 \mathrm{~km} / \mathrm{h}$ では波長 $10 \mathrm{~m}$ を最大として波長 9 〜11m で 1.1 程度, さらに走行速度 $100 \mathrm{~km} / \mathrm{h}$ では波 長 $11 \mathrm{~m}$ を最大として波長 $10 \sim 12 \mathrm{~m}$ で 1.2 程度であ った. 走行速度の増加とともに動的増幅率が 1.0 を 超える波長領域が長くなっていることがわかる。す なわち, 走行速度 $80 \mathrm{~km} / \mathrm{h} \sim 100 \mathrm{~km} / \mathrm{h}$ で走行した場 合, 走行速度の増加とともに車両のばね振動を大き く加振する波長領域が増え, 主桁の動的増幅率も大 きくなることが明らかとなった。 


\section{0. まとめ}

本研究で対象とした橋梁では, 第 2 走行車線の伸 縮継手付近の路面凹凸が $10 \mathrm{~m}$ 程度の周期性を有し ていた。この周期性の路面凹凸の影響により, 大型 車両のばね上振動が増幅され, さらにその状態で橋 梁上を走行することにより, 車両と橋梁の連成振動 が生じ, 主析に大きな動的応力が生じていた. 試験 車両を用いた走行実験，一般車走行による補修前後 のモニタリングから，周期性路面が橋梁に及ぼす影 響について明らかにした。

また, 解析的なアプローチとして, 車両走行シミ ユレーションを行い, 解析上で伸縮継手近傍におけ る路面凹凸の波長や車両の走行速度を変化させた場 合，周期性路面が橋梁に及ぼす動的な影響について 解析からも検討した.

本研究により得られた知見は以下の通りである.

1) 補修前において, 周期性路面を有していた第 2 走行車線の IRI は, 縦断方向の凹凸に対する補 修目標值 IRI:3.5mm/m を超過していた。また, 路面補修により, IRI の低減が明らかであった。

2) 路面の補修前後において, 試験車を用いた様々 な走行パターンによる橋梁の応答の変化につい て調べた。その結果, 動的増幅率としては, 3 軸トラックが第 2 走行車線を走行したケースが 最も大きかった.

3) 橋梁のたわみに伴う曲げひずみから走行荷重群 の載荷荷重を推定する方法を考案し, 推定精度 が十分あることを確認した。

4) 対象橋梁のたわみ 1 次振動は, 補修前において 振動数 $2.975 \mathrm{~Hz}$, 減衰定数 $0.0145 \sim 0.0155$ に最 も多く分布していた。一方, 補修後では, 振動 数 $2.980 \mathrm{~Hz}$, 減衰定数 0.015 に最も多く分布して おり, 補修前後において振動特性の大きな変化 は見られなかった。

5) 日最大載荷荷重は, 補修前後ともに概小 500～ $1000 \mathrm{kN}$ の範囲に分布していた. 補修前の平均值 は $721 \mathrm{kN}$ ，補修後は $666 \mathrm{kN}$ であった。モニタリ ング期間に計測された最大載荷荷重は, 設計活 荷重の半分程度となる $1150 \mathrm{kN}$ を超えていなか った。また, 頻度の多い載荷荷重は, 100〜 200kNであった.

6) 補修前の日最大応力度の平均値は $2.0 \mathrm{~N} / \mathrm{mm}^{2}$ であ り, 概ねセミトレーラ 2 台並走による試験走行 実験の結果と一致していた。一方, 補修後の日 最大応力度の平均值は $1.2 \mathrm{~N} / \mathrm{mm}^{2}$ 程度であった. 補修前後の平均值で比較すると補修により日最 大応力度は $40 \%$ 低減した。
7) 日々の最大動的増幅応力は, 載荷荷重が大きな 領域（400〜800kN）で大きな動的増幅応力が発 生していることが明らかとなった。これより， 比較的大きい走行荷重群の車両と周期性路面お よび橋梁との連成振動により応力度が増幅して いた。 これに対して路面補修後では, 車両と橋 梁との連成振動が小さくなり, 動的増幅応力が 大きく低減し, どの載荷荷重領域においても平 均的な動的増幅応力になった.

8) 補修前後において, 日々の動的増幅率として最 も頻度が多かった載荷荷重と動的増幅率の組み 合わせは, 補修前において載荷荷重 $170 \mathrm{kN}$, 動 的増幅率 0.2 , 補修後において載荷荷重 $170 \mathrm{kN}$, 動的増幅率 0.1 であった。

9) 補修前の最大動的増幅応力は $400 \sim 800 \mathrm{kN}$ の載 荷荷重により発生していたが，各載荷荷重にお ける動的増幅率（DIF-1）の最大值は, 右下がり の反比例の関係になっていた。 また, 路面補修 前後ともに $800 \mathrm{kN}$ 付近では動的増幅率 (DIF1）が $0.0 \sim 0.2$ に多く分布していた. したがって, このような載荷荷重が大きな領域での動的増幅 率は, 周期性路面の影響よりも橋梁上に存在す る走行荷重群の載荷荷重に支配されていること がわかった。

10)解析上で伸縮継手近傍における路面凹凸の波長 および走行速度を変化させて車両走行シミュレ ーションを行った結果, 走行速度 $80 \mathrm{~km} / \mathrm{h} \sim$ $100 \mathrm{~km} / \mathrm{h}$ で走行した場合, 走行速度の増加とと もに車両のばね振動を大きく加振する波長領域 が増え, 主桁の動的増幅率も大きくなることが 明らかとなった。

\section{参考文献}

1) 室井智文, 薄井王尚, 樅山好幸, 深田宰史, 梶川康男, 幸田信則 : 伸縮継手付近の路面凹凸の影響を受けた大 型車両と PC桁橋の振動特性, 構造工学論文集, Vol.54A, pp.171-180, 2008.3.

2) 梶川康男, 深田宰史, 林下貴彦, 山田健太郎, 小塩達 也 : サスペンション構造が異なった車両走行による高 架橋の振動特性, 構造工学論文集, Vol.50A, pp.413420, 2004.

3) Green, M. F., Cebon, D. and Cole, D. J.: Effects of vehicle suspension design on dynamics of highway bridges, Journal of Structural Engineering, Vol.121, No.2, pp.272282, 1995.

4) 広井智, 樅山好幸, 讃岐康博, 岡田裕, 兼澤秀和: 路 面プロファイル測定システムの開発, 土木学会年次学 術講演会概要集, V-067, 2009.9. 
5) Sayers, M. W. (笠原篤, 関口幹夫，加藤昌太郎 訳） : 道路縦断プロファイルからの IRI の算出（上）, 舗装, Vol.31, No.7, pp.21-27, 1996.7.

6) Sayers, M. W. (笠原篤, 関口幹夫, 加藤昌太郎 訳) : 道路縦断プロファイルからの IRI の算出（下），舗装， Vol.31, No.8, pp.12-17, 1996.8.

7) 東日本 - 中日本 - 西日本高速道路株式会社 : 設計要領 第一集 舗装編, p.134, 2007.8.

8) 土木学会 : 構造工学シリーズ10 橋梁振動モニタリン グのガイドライン, pp.173-175, 2000.1.

9) 岡林隆敏, 系永洋次郎, 木場俊郎, 奥松俊博 : 携帯電 話インターネット機能による遠隔振動モニタリングシ ステムの開発，構造工学論文集，Vol.49A，pp.299307, 2003.3.

10) 奥松俊博, 岡林隆敏, 田代大樹, 要谷貴則, Jawaid Bashir AHMAD : 橋梁遠隔モニタリングシステムによ る鋼ランガートラス橋の固有振動数の推移観測, 構造 工学論文集, Vol.53A, pp.844-852, 2007.3.

11) 小塩達也, 森田俊樹, 深田宰史, 山田健太郎, 梶川
康男：自動車荷重と橋梁・地盤振動の同期モニタリン グ，構造工学論文集，Vol.50A，pp.395-402，2004.3.

12) 西川和廣, 村越潤, 宮崎和彦: 橋梁を用いた車両重 量の計測（WIM） システムの開発，土木技術資料， Vol.38, No.1, pp.8-9, 1996.1.

13) 三木千寿, 村越潤, 米田利博, 吉村洋司: 走行車両 の重量測定，橋梁と基礎，Vol.21，No.4，pp.41-45, 1987.

14) 小塩達也, 山田健太郎, 小林直人, 水野良浩: 鋼I桁 橋の縦桁を用いたBridge Weigh-in-Motionシステムの開 発, 構造工学論文集, Vol.47A, pp.1083-1091，2001.3. 15) 米田昌弘，枝元勝哉：遺伝的アルゴリズムを適用し たBridge Weigh-in-Motionシステム, 構造工学論文集, Vol.50A, pp.707-718, 2004.3.

16) Juang, J. N. and Pappa, R. S.: An eigensystem realization algorithm for modal parameter identification and model reduction, Journal of Guidance, Vol.8, No.5, pp.620-627, Sept.- Oct., 1985.

\title{
DYNAMIC RESPONSE OF BRIDGE AFFECTED BY ROAD ROUGHNESS WITH A LONG SPATIAL WAVELENGTH IN MONITORING BEFORE AND AFTER REPAIR
}

\author{
Saiji FUKADA, Tomofumi MUROI, Yoshiyuki MOMIYAMA \\ and Yasuo KAJIKAWA
}

Object prestressed concrete bridge with a $37.47 \mathrm{~m}$ span vibrated greatly due to the resonation of the leaf suspension spring vibration arose from road roughness with the spatial wavelength near the expansion joint, only when the test truck ran in the $2^{\text {nd }}$ slow lane. The bridge dynamic response affects the driver's riding comfort and the load-carrying capacity of the bridge. The monitoring was carried out for two years and five months in order to grasp the dynamic stress of the girders and the total weight of the trucks ordinarily running on the bridge. Moreover, the road roughness with a long spatial wavelength was repaired. After the repair, the same monitoring is continuing currently in order to compare with the data gathered about the dynamic response of the bridge before the repair. This paper describes the results of the dynamic response of the bridge resonated to the trucks' spring vibration arose from road roughness with a long spatial wavelength by monitoring before and after the repair. 